\title{
Użycie słowa "czas” w Księdze Syracydesa
}

\author{
Use of the Word "Time" in the Book of Ben Sirach
}

\author{
ANDRZEJ DEMITRÓW \\ Uniwersytet Opolski \\ ademitrow@uni.opole.pl, ORCID: 0000-0002-2643-7185
}

\begin{abstract}
Streszczenie: Artykuł ma na celu przedstawienie użycia słowa „czas” w Księdze Syracydesa. W tym celu autor syntetycznie ukazał najpierw pole semantyczne terminu „czas” w języku hebrajskim i greckim. Następnie, na podstawie wskazanych rozróżnień, zostały przedstawione fragmenty, w których pojawia się omawiany termin, z uwzględnieniem kontekstu całej księgi, jak i pozostałych ksiąg biblijnych. Dla mędrca z Jerozolimy czas nie jest jedynie pojęciem wyznaczającym chronologię, ale rzeczywistością, którą codziennie człowiek odkrywa jako sposobność do czynienia dobra i przestrzeń działania Boga jako Stwórcy i Pana całego stworzonego świata. Różnorodność sytuacji życiowych, które przedstawia Ben Syrach w swej księdze, czynią go prawdziwym nauczycielem i świadkiem owocnie przeżytego czasu życia.
\end{abstract}

Słowa kluczowe: czas, chwila sposobna, właściwa pora, okazja, Księga Syracydesa

Abstract: The purpose of this article is to present the use of the word "time" in the Book of Sirach. To this end, the author synthetically presents, first, the semantic field of the term "time" in both Hebrew and Greek. Then, based on these distinctions, the fragments in which the term appears are presented, taking into account the context of the whole book, as well as other biblical books. For the sage of Jerusalem, time is not just a chronological concept, but a reality which man discovers every day, as both an opportunity to do good and also a space for God, as Creator and Lord of the whole created world. The variety of life situations that Ben Sirach presents in his book make him a true teacher and witness to a fruitful life.

Keywords: the time, the right moment, the right time, opportunity, the Book of Ben Sirach

Spośród wielu zagadnień, które znajdują się u podłoża refleksji ogólnoludzkiej, kwestia czasu zajmuje jedno z najważniejszych miejsc. Nie dziwi więc fakt, że w literaturze mądrościowej biblijnego Izraela zagadnienie to stało się przedmiotem szczególnej wagi, zwłaszcza w konfrontacji z cywilizacjami starożytnego Bliskiego Wschodu i cywilizacją helleńską ${ }^{1}$. Najwymowniejszym przykładem tej konfrontacji w literaturze biblijnej pozostaje Księga Koheleta, w której wyrażenie עת („czas”), najczęściej tłumaczony w tekście LXX słowem kaıpó, pojawia się aż 40 razy w 12 rozdziałach, ze szczególnym znaczeniem obecnym w Koh 3,1-8. Nie powinien dziwić fakt, że w czasowo późniejszej Księdze Syracydesa, bazując na odnalezionych fragmentach

1 Ogólny zarys zagadnienia czasu w perspektywie kultury starożytnej, zob.: Bielecki, Kaıpóৎ, 37-69. Ujęcie problematyki od strony biblijnej, zob: Join-Lambert - Grelot, „Czas”, 175; Stachowiak, „Teologiczno-biblijna problematyka czasu”, 291-303; Bielecki, „Ujęcie”, 58-60; Jankowski, Biblijna teologia czasu, 7-56. 


\section{ANDRZEJ DEMITRÓW}

hebrajskiego tekstu, wyrażenie עת („czas”) występuje ok. 37 razy, w zależności od zachowanych rękopisów ${ }^{2}$. Biorąc pod uwagę jego greckie tłumaczenie słowem kaıpó w LXX, liczba ta jest dużo większa w całości zachowanej Księgi Syracydesa i wynosi 56 razy. Po Księdze Koheleta właśnie ta księga zawiera największą liczbę przypadków użycia tego słowa w różnych kontekstach. O ile jednak zbiór refleksji mędrca, znanego jako „panującego w Jeruzalem” (Koh 1,1), jest stosunkowo dobrze opracowany pod względem znaczenia tego terminu ${ }^{3}$, o tyle późniejsza czasowo Księga Syracydesa wciąż czeka na jego głębsze opracowanie monograficzne, tym bardziej że większość dotychczasowych studiów podkreśla wyraźnie istniejącą kontynuację myśli mądrościowej ${ }^{4}$.

Podstawową jednak trudnością w badaniach nad księgą mędrca z Jerozolimy jest jej niejednolity i bardzo złożony przekaz w tradycji hebrajskiej i greckiej. Uczeni są zgodni, że Księga Syracydesa została ułożona około 180 r. przed Chr. w języku hebrajskim. Wnuk autora przełożył ją około 117 r. przed Chr. w Egipcie na język grecki. Tekst hebrajski, znany i czytany jeszcze w I w. po Chr., zwłaszcza w Qumran, został zakazany w oficjalnej lekturze synagogalnej. Wersja grecka stała się tekstem podstawowym (kanonicznym) dla chrześcijan i źródłem dla tekstu łacińskiego oraz dla innych tłumaczeń. W 1896 r. i w późniejszych latach odkryto znaczne partie tekstu hebrajskiego w genizie w Kairze, a w 1964 r. kilka rozdziałów tekstu hebrajskiego znaleziono na Masadzie. Zarówno greckie, jak i hebrajskie tradycje tekstowe mają krótkie i długie recenzje, co stwarza wiele tekstowych problemów. Fragmenty hebrajskie uważa się ogólnie za autentyczne, choć istnieją pewne dowody ich wtórnego tłumaczenia z wersji syryjskiej. Stąd jawi się zrozumiała trudność w analizie księgi o tak skomplikowanej sytuacji tekstualnej ${ }^{6}$. Choć należy uznać, że tekst hebrajski jest niekompletny i zróżnicowany nawet we wspólnych fragmentach, odnalezionych w Kairze czy na Masadzie, to równocześnie nie powinno się ignorować jego istnienia, zwłaszcza w badaniach naukowych nad poszczególnymi fragmentami czy stosowaną terminologią. Wielu egzegetów wyznaje zasadę, że tekst hebrajski i tekst grecki to są dwie zupełnie różne wersje i nie można ich traktować wymiennie. Decyzja metodologiczna wyboru jednej z nich (najczęściej greckiej), z pominięciem tekstu hebrajskiego, jest w pełni uzasadniona. Warto jednak, dla dalszych badań nad istniejącymi

2 Gilbert, „Il concetto”, 69.

3 Warto wymienić przynajmniej niektóre ważniejsze publikacje: Wilch, Time and Event, 117-128; Lohfink, „Le temps dans le livre de Qohélet”, 69-80; Lys, L'Ecclésiaste ou que vaut la vie?, 302-345; Sacchi, „Il problema del tempo in Qohelet", 73-83.

4 Syntetycznie tę zależność ukazał Maurice Gilbert („Il concetto”, 69-89). Por. także dotychczasowe przyczynki które, choć fragmentaryczne, wiele wnoszą w stan badań nad zrozumieniem pojęcia czasu w Księdze Syracydesa: Wilch, Time and Event, 138-143; von Rad, La sapienza in Israele, 235-252; Fox, A Time to Tear Down, 194-206; Liesen, Full of Praise, 189-276.

5 Na temat historii tekstu Syracydesa i jego tłumaczeń, zob. Obruśnik, „Księga Syracydesa”, 59-69; Gilbert, Les cinq livres, 149-154.

6 Zob. Piwowar, „La storia”, 31-53, który zawiera bardzo obszerne i szczegółowe ukazanie złożoności tej sytuacji. 
rękopisami, podjąć wyzwanie ich porównania, zwłaszcza w tych fragmentach, które zachowały się w języku oryginalnym. Stąd, uwzględniając istniejące różnice i zastrzeżenia badaczy co do stanu rękopisów hebrajskich Księgi Syracydesa, w obecnym studium nad użyciem terminu kaıpóৎ „czas” podstawą będzie tekst grecki, jednak opatrzony porównawczo tekstem hebrajskim, jeśli taki się zachował.

\section{Pole semantyczne terminologii czasu}

Należy zauważyć, że ten na pozór jednoznaczny termin, określający jednostkę „czasu” w aspekcie chronologicznym (por. Rdz 24,11; Ag 1,2), w tekstach biblijnych pozostaje otwarty na szersze rozumienie w innych aspektach.

Analizując występowanie tego słowa w świetle kontekstu bliższego, autorzy podkreślają znaczenie terminu kaıpó (który najczęściej jest tłumaczeniem hebrajskiego słowa עי (ע) ${ }^{7}$ jako „czasu”, który stanowią wydarzenia bądź sytuacje przewidywalne (zob. Rdz 18,10.14; Mi 5,2), lub oczekiwane (Ps 102,14), będące zarazem „sposobnością" do wykonania określonej czynności albo „właściwą, słuszną porą” dla zaistnienia pewnych faktów (zob. Rdz 29,7). Jednak perspektywa autorów biblijnych nie zamyka się jedynie w doczesności, lecz wyraźnie ukierunkowuje na Boga, który jako jedyny zna „czas” życia człowieka (zob. Koh 9,12) i określa „czas sposobny” dla narodu (por. Ez 16,8), jak też „porę sądu” osobistego, czyli ujawnienia skutków ludzkich decyzji i postępowania (zob. Iz 13,22; Ez 22,3) ${ }^{8}$. Gdy rzeczownik kaıpó ৎ jest

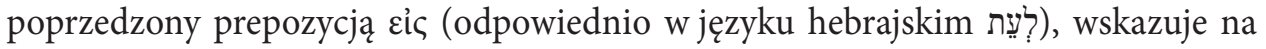
właściwy czas dla czegoś, dla jakiegoś działania czy też wydarzenia. Ten czas dla daje człowiekowi sposobność do działania, którą on winien wykorzystać, przy czym ta sposobność realizuje się zarówno na płaszczyźnie życia codziennego, jak i w sferach o charakterze religijnym? 9

7 Zdaniem Stanisława Bieleckiego (Kaıрóৎ, 71-72) słowo עי jest najczęstszym hebrajskim terminem na ozna-

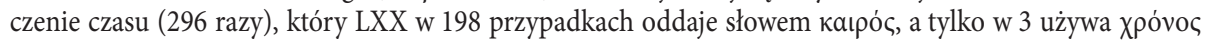
(Jr 30H,7 = 387G,7;31H,1 = 38G,1; 49H,8 = 30G,2). Cytując badania Luisa Alonso Schökela, podaje następujące znaczenia słowa ע: czas, dzień, godzina, moment, epoka, okres czasu, odpowiednia chwila, pora roku, położenie, krótki termin, koniec, kres, okazja, sposobność. Termin grecki kaıpós wyraźnie nieprzypadkowo posłużył w tłumaczeniu LXX do oddania tej złożonej rzeczywistości. W pewnym sensie ma ono to samo znaczenie co עת, oczywiście zawsze z uwzględnieniem kontekstu, w którym zostało użyte przez tłumaczy.

8 W świetle tych tekstów można mówić w przypadku terminu עת o momencie wyjątkowym, specjalnym, w którym dzieje się coś ważnego (często po długotrwałym oczekiwaniu) - to pewna chwila właściwa, czas uprzywilejowany, który ma wyjątkowe znaczenie w historii lub dla życia człowieka. Por. szczegółowe analizy terminu: HALAT I, 835-836; Jenni, „עת", THAT II, 370-385; Kronholm, ,עתAT VI, 464-483; Delling, „кaıрóৎ”, TDNT IX, 458-459; Lust - Eynikel - Hauspie, A Greek-English Lexicon of the Septuagint II, 222; Montanari, Vocabolario della lingua greca, 1034; Muraoka, A Greek-English Lexicon of the Septuagint, 335-336; Romizi, Greco antico, 651.

Bielecki, Kaıюóৎ, 72. 


\section{ANDRZEJ DEMITRÓW}

Tę różnorodność rozumienia terminu kaıpó można sprowadzić do dwóch zasadniczych przestrzeni: bardzo często łączy się ze zjawiskami natury bądź z wydarzeniami z ludzkiego życia ${ }^{10}$. Odpowiada to dwom, często między sobą zależnym, aspektom czasu, które wyróżniają już najstarsze księgi Starego Testamentu. Pierwszy z nich opiera się na obserwacji ciał niebieskich i związanych z tym przemian w przyrodzie, drugi natomiast łączy się z szeregiem wydarzeń, które kształtują losy narodu wybranego i tworzą historię w ścisłym tego słowa znaczeniu ${ }^{11}$.

To sumaryczne przedstawienie jest jedynie szkicową ilustracją bogactwa znaczeniowego omawianego terminu i wymaga dookreślenia w przypadku poszczególnych ksiąg, z którym można zapoznać się w pozostałych przyczynkach niniejszego tomu, jak też w pozycjach podanych w bibliografii. Dla omawianego tematu jest $w$ tym miejscu istotne wskazanie, w jaki sposób mędrcy Izraela, a wśród nich także Syracydes, postrzegali kwestię czasu. Według Mauricea Gilberta ${ }^{12}$ dotychczasowe badania egzegetyczne nad tym terminem w literaturze mądrościowej pozwalają na wyróżnienie dwóch grup znaczeniowych:

a) dotyczy szeroko rozumianego aspektu czasowego, gdy analizowany termin wskazuje na jednostkowe wydarzenie (np. śmierć człowieka) lub na powtarzalność jakiegoś faktu, np. świąt, w określonych porach dnia, miesiąca i roku ${ }^{13}$;

b) odnosi się do wydarzeń i ich okoliczności, spośród których można wyróżnić bądź konkretne i realne wydarzenie, bądź ogólny zbiór sytuacji, które mogą mieć miejsce przy zaistnieniu odpowiednich okoliczności i w określonym kontekście.

Jest rzeczą oczywistą, że mędrcy Izraela odnoszą się do sytuacji z życia ludzi, ale nie uciekają od odpowiedzi na pytanie o obecność Boga i jego ingerencje w te sytu$a \mathrm{cjj}^{14}$. Ostatecznie to właśnie Bóg determinuje rzeczywistość czasu, choć w każdej z ksiąg spotkać można nieco odmienne rozłożenie akcentów. Posługując się powyższym podziałem, jest możliwa dokładniejsza analiza niektórych miejsc występowania terminu kaıpóৎ („,czas”) u Syracydesa na podstawie wybranych, najważniejszych fragmentów jego księgi.

10 Muilenburg, „View of Time”, 234-235.

11 Stachowiak, „Teologiczno-biblijna problematyka czasu”, 294-295.

12 Gilbert, „Il concetto”, 78-79.

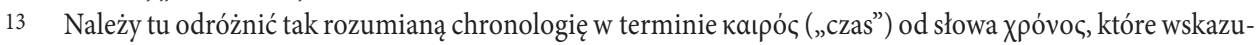

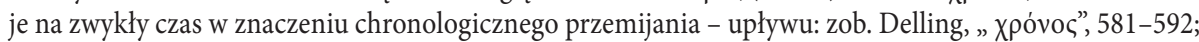
Lust - Eynikel - Hauspie, A Greek-English Lexicon of the Septuagint, II, 520; Montanari, Vocabolario della lingua greca, 2376-2377; Muraoka, A Greek-English Lexicon of the Septuagint, 737-738.

14 Wilch, Time and Event, 138-143; von Rad, La sapienza in Israele, 235-252; Fox, A Time to Tear Down, 194-206. 


\section{Rozumienie czasu w Księdze Syracydesa}

\subsection{Termin Kaıpóc („czas”) w aspekcie chronologicznym}

a) czas i dzień śmierci człowieka jako kresu życia

Dla mędrca czasem pojętym w aspekcie chronologicznym jest przede wszystkim moment śmierci, który dla każdego człowieka jest określony i nieunikniony, choć nie do przewidzenia.

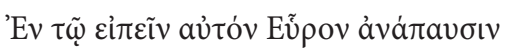

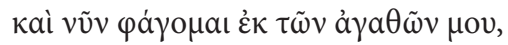

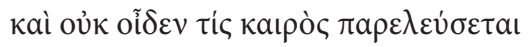

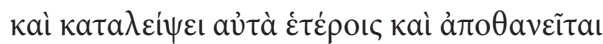
„W powiedzeniu sobie: «Znalazłem odpoczynek i teraz zjem z dóbr moich» a nie wie, jaki czas przyjdzie i pozostawi je innym i umrze" (Syr 11G,19) ${ }^{15}$.

Tekst hebrajski z rękopisu A jest w tym miejscu uszkodzony, choć zachowały się kluczowe słowa:

מצאתי נחת ועתה אכל [...] ובעת

„I w dogodnym czasie [...] znalazłem spokój i teraz mogę...” (Syr 11H,19).

Opisana przez mędrca sytuacja ma swoje nowotestamentowe echo w słowach przypowieści Jezusa o bogaczu, który liczył na długie i dostatnie życie, zapewnione dzięki nagromadzonym dobrom (por. Łk 12,16-21) ${ }^{16}$. Głupotą jest pokładanie ufności w tym, co nie zapewni długowieczności, a moment śmierci kończy nieodwracalnie to ziemskie życie (por. Hi 27,16-23; Ps 49,17-18; Koh 2,21-23) ${ }^{17}$. Stąd rada Syracydesa we fragmencie poświęconym przygotowaniu do śmierci, dotycząca uporządkowania spraw materialnych, gdy nadejdzie chwila odejścia:

בעת מספר מצער ימיך

ליום המות הנחל מספר מצער

„W czasie policzonym pomniejszenia twoich dni, w dniu śmierci rozdaj dziedzictwo" (Syr 33H,24).

15 Wojciechowski, Księgi greckie, 542-543.

16 Langkammer, Ksiega Syracha, 114; Sauer, Jesus Sirach, 112.

17 Schreiner, Jesus Sirach, 70; Palmisano, Siracide, 130. Szerzej na ten temat w całej Księdze Syracydesa, zob. Popielewski, „Refleksja Syracha”, 61-84. 


\section{ANDRZEJ DEMITRÓW}

Tekst grecki zawiera nieco odmienną wersję:

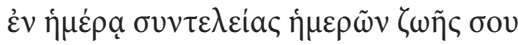

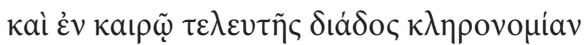

„W dniu dopełnienia dni życia twego

i w czasie śmierci rozdaj dziedzictwo" (Syr 33G,24) ${ }^{18}$.

בעת Należy zauważyć, że mędrzec w tekście hebrajskim, paralelnie do terminu („w czasie”), używa wyrażenia czasowego ביום („w dniu”) z wyraźnym podkreśleniem aspektu chronologicznego opisywanej sytuacji. Tłumacz grecki odczytał ten

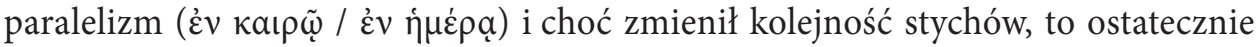
zachował ich sens. Paralelizm synonimiczny: czas i $d z i e n ́$, występuje dość często u Syracydesa (por. Syr 5H,7; 6H,8; 17G,2; 18G,24-25; 30H,24). Również wtedy, gdy słowu יוֹ „dzień”, tłumaczonemu przez wnuka terminem $j \mu \varepsilon \dot{\varepsilon} \rho$, nie towarzyszy paralelnie termin עת i kaıpó („czas”), to mamy do czynienia z zaakcentowaniem konkretnego momentu, określonych okoliczności: narodziny (zob. Syr 23G,14), modlitwa (zob. Syr 3G,5); składanie ofiar (Syr 45H,14), utrapienie i przykrości (zob. Syr 3H,15; 6H,8.10; 11G,25), nieszczęście (zob. Syr 5H,7-8), chwała (zob. Syr 11H,4), pomyślność (zob. Syr 11H,25; 14H,14), panowanie grzechów (zob. Syr 18G,27), zwycięstwo w walce (zob. Syr 46H,4), śmierć (zob. Syr 1G,13; 11G,26; $38 \mathrm{H}, 17 ; 40 \mathrm{H}, 1-2)$.

Niejednokrotnie sam termin „dzień” pojawia się w liczbie mnogiej, zarówno

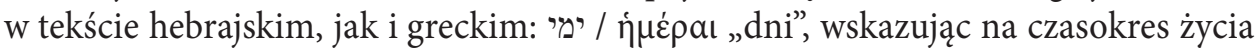
człowieka i ludzi w aspekcie ogólnym (por. Syr 1G,2; 3H,12-13; 18G,9-10; 22H,12; 23G,15; 24G,25-27; 26H,1; 30H,24; 33G,7; 33H,9; 37H,25a; 38G,27; 40G,6; 40H,23; $41 \mathrm{H}, 13 ; 42 \mathrm{H}, 9)$ bądź chronologii życia ważnych postaci czy też całego narodu wybranego (zob. Syr 36H,13; 37H,25b; 44H,7; 45H,15; 46H,1.7; 47G, 1; 47H,13; 48H,12; 48H,18; 48G,23; 49H,3; 49G,12; 50H,1; 50G,3; 50H,6.8.24; 50G,22-23; 51G,10). Nawiązując do dnia śmierci, Syracydes wyraźnie odnosi się do postaci wielkich postaci biblijnych, które w ten właśnie sposób rozporządzili swoim dziedzictwem pod koniec swego życia i w chwili swego odejścia przekazali błogosławieństwo potomnym (por. Izaak: Rdz 27,1-40; Jakub: Rdz 49,1-28; Dawid: 1 Krl 2,1-11) ${ }^{19}$.

Do momentu śmierci powraca Syracydes dwukrotnie wychwalając postać Samuela - za skuteczną modlitwę wstawienniczą podczas walk z Filistynami, a zwłaszcza za jego nieprzejednaną postawę wierności wobec Boga i namaszczonego władcy (por. Syr 46,13-20) ${ }^{20}$ :

\footnotetext{
18 Wojciechowski, Księgi greckie, 630.

19 Sauer, Jesus Sirach, 236. Zdaniem Patricka W. Skehana i Alexandra A. Di Lella (Wisdom of Ben Sira, 405) to zdanie potwierdzałoby tezę, że w czasach Syracydesa w Palestynie spisanie ostatniej woli i testamentu nie było czymś powszechnym. 
„i czasem swego położenia się na łożu (śmierci)

wezwał na świadka Pana i jego namaszczonego" (Syr 46H,19ab) ${ }^{21}$.

Tłumacz grecki przełożył dosadnie obraz zawarty w tekście hebrajskim jako moment śmierci Samuela:

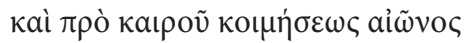

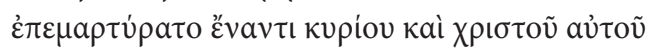

„i przed czasem wiecznego spoczynku

dał świadectwo przed Panem i jego pomazańcem" (Syr 46G,19ab) ${ }^{22}$.

Wierność Samuela dotyczyła jego uczciwości w sprawowaniu sądów nad narodem wybranym, $\mathrm{z}$ widocznym odniesieniem do unikania stronniczości na rzecz sko-

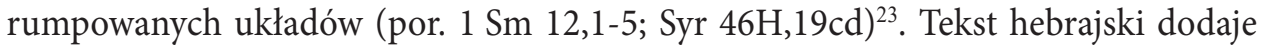
jednak ważną uwagę, której nie ma w tekście greckim, a która nawiązuje powtórnie do momentu śmierci Samuela:

וגם עד עת קצו נבון נמצא

בעיני ייי ובעיני כל ער קו נבון נמי

„I także aż do czasu swego końca okazał się być człowiekiem mądrym,

w oczach Pana i wszystkich żyjących" (Syr 46H,19ef) ${ }^{24}$.

Mędrzec wyraźnie ukazuje więc Samuela w pespektywie jego ostatecznego odejścia z ziemi żyjących, ale równocześnie podkreśla jego postawę mądrości i rozsądku zachowywaną przez całe jego życie. W tym sensie wyrażenie עד עד קצ ,aż do czasu swego końca" akcentuje nie tyle sam punkt finalny, co bardziej podprowadza pod charakterystykę całej egzystencji zwieńczonej momentem śmierci ${ }^{25}$. Stąd też w innych miejscach mędrzec podkreśla znaczenie tej decydującej chwili, która, choć nieunikniona i napawająca obawą $(\text { Syr } 40 \mathrm{H}, 1)^{26}$, związana ze smutkiem żałoby po odejściu osoby (Syr 22H12; 38H,17), będzie czasem rekompensaty od Pana według

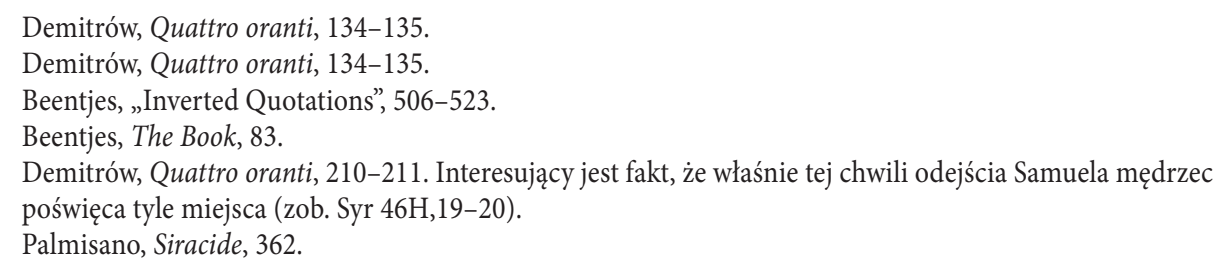




\section{ANDRZEJ DEMITRÓW}

postępowania człowieka (Syr 9H,12; 11G,26; 11H,27) i błogosławieństwem dla tego, który trwa w bojaźni przed Nim $(\text { Syr } 1 G, 13)^{27}$.

\section{b) czas zaśnięcia i powstania po bezsennej nocy}

O aspekcie chronologicznym terminu עת / אaıpóৎ („czas”), ale ze wskazaniem na powtarzalność czynności w określonych porach, Syracydes wspomina, opisując kruchość życia człowieka i jego cierpienia (por. Syr 40,1-7)28. Rzecz znamienna, że wprowadzeniem do tej refleksji jest wspomniane wyżej wyrażenie יiأ „dzień” w bardzo specyficznej formule, obejmującej całość życia ludzkiego: „Od dnia, w którym wychodzi się z łona matki, do dnia, w którym wraca do matki wszystkich żyjących” (Syr 40H,1b). Następnie mędrzec przytacza prawdę o powszechności rozmaitych emocji: gniewu i zazdrości, niepokoju i niepewności, lęku przed śmiercią i nienawiści oraz kłótni (por. Syr 40,2-4) ${ }^{29}$, które dodatkowo zobrazował bezsennym doświadczeniem nocy. Ze względu na stan tekstu Syr 40H,5-7, który zachował się fragmentarycznie (ועת נוחו על משכבו , , w czasie odpoczynku w łóżku”), w analizie trzeba się oprzeć na tekście greckim³0.

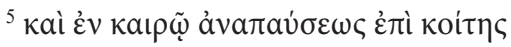

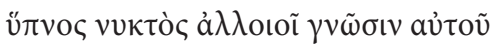

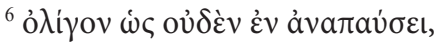

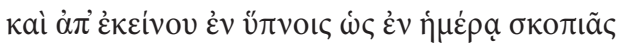

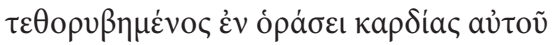

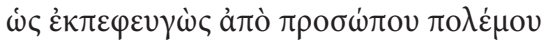

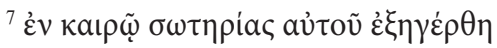

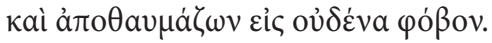

5 "Nawet w czasie spoczynku na łóżku,

Sen nocy niepokoi jego umysł.

${ }^{6}$ Mało, prawie nic w spoczynku

I od tego w snach jakby w dzień na czatach

Przerażony widmami swego serca,

Jakby uciekał przed wrogiem.

${ }^{7} \mathrm{~W}$ czasie swego ocalenia budzi się

I dziwi się ze swego bezpodstawnego strachu" (Syr 40G,5-7) ${ }^{31}$.

27 Skehan - Di Lella, Wisdom of Ben Sira, 144.

28 Palmisano, Siracide, 363.

29 Zdaniem Hugolina Langkammera (Księga Syracha, 325) w wyliczaniu wad Syracydes „zachowuje pewną logikę, wyrażoną w formie literackiej. Wady te można zaliczyć do grupy cierpień psychicznych, które uszeregował w pary w stosunku paralelizmu synonimicznego. Zauważa się też użycie systemu gradacyjnego jak w klasycznym sylogizmie od - do ('a' lub 'ab' usque 'ad')”. Zob. też Popielewski, „Refleksja Syracha”, 69: mędrzec „przedstawia swoiste katalogi zła, jaki może nawiedzić i de facto nawiedza człowieka w czasie jego życia; za każdym razem śmierć jest włączona w ów katalog jako jeden z elementów tego zła”. Beentjes, The Book, 69; Palmisano, Siracide, 364-365.

31 Langkammer (Księga Syracha, 325) zauważa, że w tekście Syr 40G,7a liczne rękopisy LXX zawierają wy-

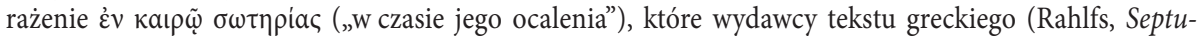


Mędrcowi wyraźnie nie są obce doświadczenia bezsennych nocy, którym towarzyszy głębokie przygnębienie i koszmary spowodowane trudnymi sytuacjami życia. To, co się wydarzyło pomiędzy zwaśnionymi i skłóconymi, przenosi się w nocy na odpoczynek, który staje się nie do zniesienia pośród walk wewnętrznych. „Tragedia tkwi nadto w niemożności wyzbycia się nocnych widm, wrogów wypoczynku, od których ucieka bez skutku. Po przebudzeniu się człowiek uświadamia sobie, że to były tylko sny, niemniej jednak nie wstaje wypoczęty"32. Te doświadczenia opisywali już poprzednicy Syracydesa, podkreślając, że człowiek żyje pośród ustawicznych zmagań (por. Ps 39,5-7; Hi 7,1-21; Koh 2,22-23) ${ }^{33}$. Wskazane dwa momenty (кaıpóৎ): położenia się i wstania z łóżka (Syr 40,5.7), stanowią w tym przypadku określone ramy, początek i koniec, które obejmują czasokres bezsennej i koszmarnej nocy ${ }^{34}$. Kontekst całego fragmentu jednoznacznie wskazuje, że człowiek, choć kładzie się spać i wstaje o określonej przez siebie porze, nie ma ostatecznie wpływu na kształt i klimat tego czasu. Pomimo wielkich oczekiwań na odpoczynek i regenerację sił, doświadcza on nieustannych lęków i koszmarów, które ostatecznie okazują się wyobrażeniowe i bezpodstawne. To doświadczenie nocy wpisuje się w ogólny los człowieka - jako stworzenia i potomka Adama - i obejmuje całość jego życia: od narodzin do śmierci (por. Syr 40,1).

\section{c) czas wyznaczonych pór przez fazy księżyca}

Znamienny jest fakt, że mędrzec używa terminu עת / אaıрó (,czas”) ze wskazaniem na powtarzalność czynności w określonych porach, gdy wychwala Boga za dzieło stworzenia, a szczególnie za działanie i piękno księżyca (Syr 43,6-8) 35 .

„I także księżyc świecąc określa pory

Jako organ regulujący okresy i znak wieczny" $(\text { Syr } 43 \mathrm{H}, 6)^{36}$.

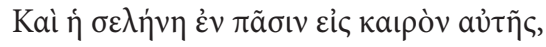

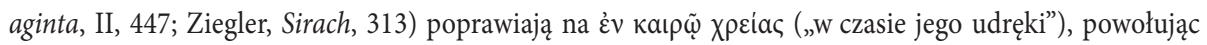
się na Syr 4,23. Należy jednak zauważyć (za Palmisano, Siracide, 365), że kontekst odnosi się do chwili przebudzenia, który jest zarazem momentem uwolnienia z przeżywanych koszmarów.

Langkammer, Ksiega Syracha, 325.

33 Palmisano, Siracide, 365.

34 Najprawdopodobniej to zestawienie jest figurą retoryczną i nosi cechy wyrażeń polarnych („biegunowych”), które wyrażają w tym miejscu całość nocy; Bazyliński, Wprowadzenie, 232. Pewne podobieństwo można zauważyć w poleceniu zawartym w Pwt 6,7, gdzie wierzący Izraelita jest wezwany, aby przypomi-

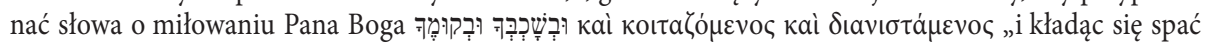
i wstając ze snu".

35 Piwowar, „Firmament”, 25-31.

36 Tekst hebrajski zachował się w dwóch nieco różniących się wersjach: w rękopisie z Masady i w rękopisie B z Kairu, który zawiera jeszcze dodatkową glosę na marginesie 43H,6a: עת עת עד עת ,czasy aż do czasu”. Tłumaczenie wersetu według analiz, które uwzględniają tę różnorodność: Palmisano, Siracide, 399. 


\section{ANDRZEJ DEMITRÓW}

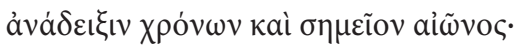

„Także księżyc we wszystkich (fazach) w swym czasie,

Wskazówka okresów i znak wieku" (Syr 43G,6) 37 .

Zdaniem Andrzeja Piwowara pierwszy stych można interpretować na dwa sposoby: „Po pierwsze, może on odnosić się do wschodu księżyca, tzn. pojawienia się go na niebie. Po wtóre, słowa te mogą określać księżyc rosnący (od nowiu do pełni). Najprawdopodobniej tekst ten odnosi się do pojawienia się księżyca na niebie, tzn. momentu lub czasu, w którym staje się on widoczny" ${ }^{38}$. Zastanawiające jest jednak, że mędrzec wyraźnie wskazuje na relację księżyca do עת / אaıpóc. Tym samym nie mówi o zwykłym czasie w znaczeniu chronologicznym, co pojawia się w kolejnym stychu, ale w znaczeniu czasu, który jest uprzywilejowany, o wyjątkowym znaczeniu w historii lub w życiu człowieka. Przypuszczalnie Syracydes odnosi się do czasu nowiu, który oznaczał początek każdego miesiąca według kalendarza księżycowego ${ }^{39}$. Ów dzień był, podobnie jak szabat, dniem odpoczynku (por. 2 Krl 4,23; 1 Mch 10,34; Ps 81,4; Iz 1,13; 66,23; Ez 46,1.3; Oz 2,13; Am 8,5), świętowania (por. Lb 10,10; $1 \mathrm{Sm}$ 20,5.24.27; Jdt 8,6; Iz 1,14) i składania ofiar (por. Lb 28,14; 29,6; 1 Krn 23,31; 2 Krn 2,3; 8,13; 31,3; Ezd 3,5; Ne 10,34; Ez 45,17; 46,6) ${ }^{40}$. Pierwszy dzień miesiąca (dzień nowiu) był więc bardzo ważnym w życiu Izraela. Z całą pewnością można do niego odnieść ע / אaıpó $\varsigma^{41}$.

Faktycznie w określeniu roli księżyca mędrzec podkreśla na pierwszym miejscu funkcję regulującą okresy w naturze (dni, miesiące i pory roku), a zwłaszcza w sprawach związanych z kultem, o czym mówi on w kolejnym wersecie, wspominając ustanowienie uroczystości i świąt pielgrzymkowych (por. Syr 43,7; 47G,10; zob. też: Wj 10,9; 23,14; Lb 28,14; $1 \mathrm{Krl} \mathrm{12,32-33;} \mathrm{Oz} \mathrm{2,13;} \mathrm{Am} \mathrm{8,5.10;} \mathrm{Iz} \mathrm{1,13;}$ $30,29)^{42}$. Tym, co sprawia, że księżyc pełni taką rolę, jest nazwanie go dwoma określeniami. Pierwszym jest termin ממשלת, przetłumaczony jako ảvá $\delta \varepsilon \xi_{\iota}$ („,wskazanie”, „oznaczenie”, „deklaracja”), które jest hapax legomenon w LXX ${ }^{43}$. Za pomocą

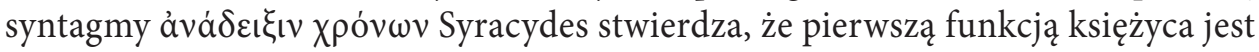
wskazywanie czasu, jego zmian i upływu. Chodzi tu nie o kaıрó „czas/moment

37 Por. tłumaczenia Wojciechowski, Ksiegi greckie, 671; Langkammer, Księga Syracha, 354.

38 Piwowar, „Firmament”, 25: „Trudno jest jednoznacznie rozstrzygnąć, która z tych interpretacji jest prawidłowa i właściwa. Za pierwszą z nich może przemawiać analogia do opisu słońca, które jest ukazane najpierw podczas wschodu".

39 Clements, ,יריז:", ThWAT III, 939-947.

40 Zob. Massouh - Verhoef, „yerah", 540; de Vaux, Instytucje, 482.

41 Piwowar, „Firmament”, 26.

42 Należy przy tym pamiętać, że od starożytności Judejczycy stosowali nie kalendarz słoneczny, ale księżycowy: Skehan - Di Lella, Wisdom of Ben Sira, 493; Palmisano, Siracide, 399-400.

43 Liddell - Scott, A Greek-English Lexicon, 103; Lust - Eynikel - Hauspie, A Greek-English Lexicon of the Septuagint, I, 27; Muraoka, A Greek-English Lexicon of the Septuagint, 39; Romizi, Greco antico, 85. 


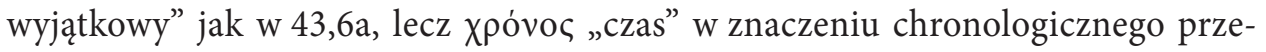
mijania - upływu ${ }^{44}$.

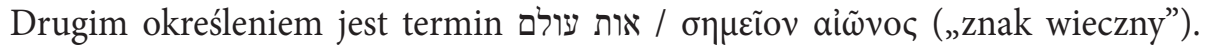
Takie nazwanie księżyca stawia go w szeregu innych znaków na niebie, uporządkowanych i ściśle zależnych od swego Stwórcy (zob. Rdz 1,14-18; 9,12). Jego osobliwe funkcyjne wyposażenie to ciągłość $\mathrm{w}$ działaniu, choć tylko w nocy, niejako uzupełniając działanie słońca w dzień. Jest to jednak znak szczególny, bo wskazuje na rzeczywistość wieczną (עולם / aĩuvoc). Można go rozumieć dwojako: bądź jako znak wieczności, wskazując upływ długich okresów czasu (wieków) ${ }^{45}$; bądź jako znak wieczny, podkreślając jego trwanie - jest on wieczny, czyli nieprzerwanie trwa na zawsze (por. Ps $72,5.7 ; 89,38)^{46}$. Kontekst bliższy sugeruje raczej pierwsze rozumienie, ponieważ rolą księżyca jest tylko „wskazywanie upływu czasu zarówno w krótkim ( $\chi \rho o ́ v o \varsigma)$, jak i długim okresie (aîuv) jego zmian i przemijania. Jedynie Bóg zna wieczność (zob. 42,18), księżyc zaś służy tylko do jej określania, tzn. wyznaczania jej okresów, ich przemijania i następowania po sobie" ${ }^{\prime \prime 7}$. W ten sposób Syracydes ujawnia ściśle biblijne myślenie o jedynym Bogu i Panu, od którego zależą wszystkie ciała niebieskie, także te, które wyznaczają czasy i pory roku z Bożego ustanowienia (zob. Syr 33,7-9)48. Człowiek winien uznać tę nadrzędność i jej się w pełni podporządkować.

\subsection{Termin kaıpóৎ („czas”) w aspekcie wydarzeń $\mathrm{i}$ ich okoliczności}

\section{a) czas nieszczęścia, strapienia i próby}

Syracydes od początku swego dzieła daje się poznać jako prawdziwy wychowawca i nauczyciel. Stąd jego pouczenia skierowane do ucznia/słuchacza, które zawierają przestrogi wobec nieuniknionych trudności na drodze zdobywania mądrości, którą mędrzec nazywa „służbą Panu” (Syr 2,1-18) ${ }^{49}$. Pośród przestróg nie brakuje jednak wskazówek, co należy robić, a czego unikać w obliczu próby $(\pi \varepsilon \iota \rho a \sigma \mu o ́ \varsigma)^{50}$ i utrapień, które stają na tej drodze (por. Syr 2G,1b-6) ${ }^{51}$. Pośród tych wskazań, dotyczących po-

44 Piwowar, „Firmament”, 26.

45 Sasse, „aìù”, TDNT I, 198-202; Argall, 1 Enoch and Sirach, 147.

46 Prato, Il problema, 178: „[...] la luna è «segno eterno», e la sua funzione è più estesa di quella di misurare il tempo".

47 Piwowar, „Firmament”, 27.

48 Langkammer, Księga Syracha, 354.

49 Pełną i wyczerpującą analizę tego rozdziału zawiera monograficzna dysertacja doktorska Nurii Calduch-Benages (En el crisol, 13-279). Zob. też skrócone opracowanie po włosku: Calduch-Benages, Un gioiello, 13-165. W języku polski analiza Syr 2,1-6, zob. Piwowar, „Wierność”, 99-126.

50 Mędrzec używa tego słowa i wyjaśnia jego znaczenie w istotnych miejscach swej księgi (zob. Syr 4,11-19;

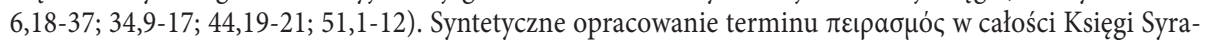
cydesa, zob. Calduch-Benages, „La prova”, 53-68.

51 Warto przypomnieć, za Andrzejem Piwowarem („Wierność”, 101), że w kodeksie 248, który jest najlepiej zachowanym, choć niekompletnym świadkiem tzw. dłuższego tekstu greckiego Księgi Syracydesa (G II), 
staw wewnętrznych i relacji do Boga, jedna odnosi się bezpośrednio do omawianej kategorii czasu i okoliczności z nim związanych (Syr 2G,2):

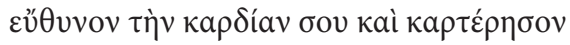

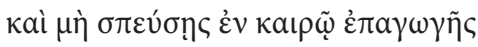

„Naprostuj serce twe i wytrwaj

I nie ponaglaj w porze przeciwności” (Syr 2G,2) ${ }^{52}$.

Polecenie mędrca, zawarte $\mathrm{w}$ tym zdaniu, stanowi ważny element $\mathrm{z}$ programu, jaki przekazuje on swemu uczniowi. W wersecie poprzedzającym mówił on $\mathrm{w}$ trybie rozkazującym o przygotowaniu duszy ucznia na $\pi \varepsilon ı \rho a \mu$ óv („próbę”, „doświadczenie"), które zawiera w sobie wewnętrzne zaangażowanie całej osoby w celu przyjęcia próby i ostatecznego pokonanie jej (por. Syr 2,17; 4,17; 6,7; 13,11; 18,23; 27,5.7; $31[34], 10 ; 36[33], 1 ; 37,27 ; 39,4 ; 44,20)^{53}$. Drugi nakaz dla ucznia dotyczy ukierun-

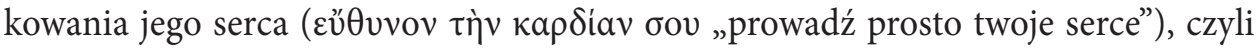
duchowego centrum życia człowieka, które w pełni winno zwracać się do Pana

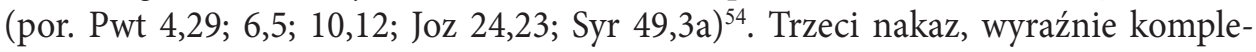
mentarny do poprzedniego, dotyczy postawy wytrwałości: bycia niewzruszonym

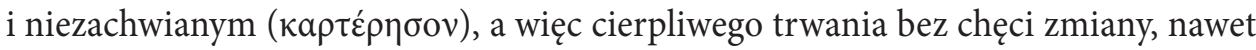
wobec niesprzyjających okoliczności (por. Hi 2,9; Iz 42,14; 2 Mch 7,17; Syr 12G,15) ${ }^{55}$.

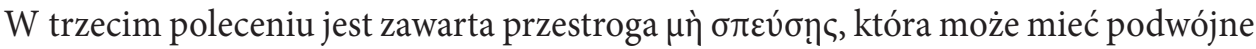
znaczenie: „nie śpiesz się, nie pędź” (por. Est 2,9; 8,14; Prz 28,12; Koh 5,1; 7,9; Dn 3,24; Syr 11G,11; 36G,10) bądź „nie obawiaj się” (por. Wj 15,15; Sdz 20,41; 1 Sm 28,21). Te dwa komponenty semantyczne - pośpiechu i strachu - pasują w tym miejscu idealnie do przestrogi mędrca, bo w obliczu jakiegoś doświadczenia można się śpieszyć, by jak najszybciej doznać uwolnienia; można też odczuwać strach i lęk wobec zagro-

fragment Syr 2,1-6 jest opatrzony nagłówkiem „O cierpliwości”. Ten grecki rzeczownik oznacza również „wytrzymałość”, „hart ducha”, „wytrwałość” i nieugiętość”. Każde z nich określa w nowy sposób treść Księgi Syracydesa i postawę człowieka w doświadczeniach. Por. Ziegler, Sirach, 133.

52 Wojciechowski, Księgi greckie, 506.

53 To może oznaczać również, zdaniem Calduch-Benages (Un gioiello, 31-33), różne doświadczenia, które niesie ze sobą wybór Pana, a które owocują postępującą dojrzałością ludzką i duchową młodego człowieka. Do nich należą, wskazane przez Syracydesa, wprowadzanie w życie przykazań (Syr 4G,17), niebezpieczeństwo śmierci (31[34],10), ofiara z własnego syna (Syr 44,20) czy własne doświadczenie mędrca na granicy śmierci (Syr 51,1-12). Zob. też Piwowar, „Wierność”, 104-105.

54 Calduch-Benages (En el crisol, 52-54) zaznacza, że choć w tym wersecie nie zostało to nazwane explicite, to wskazuje na to kontekst tego fragmentu, jak i całej Biblii. Takie ukierunkowanie zakłada pewną prawość moralną, czyli postępowanie człowieka sprawiedliwego, który żyje w bojaźni Pańskiej. Serce skierowane na Pana to cały świat wewnętrzny skoncentrowany na Bogu i scalony w Nim, który jest podstawą zdecydowanego i wiernego trwania przy podjętych decyzjach i wyborach. Przeciwieństwem jest postawa niewierności, gdy ludzie nie zwracają ku Panu swego serca (por. Ps 78,8). Zob. też Calduch-Benages, Un gioiello, 35; Piwowar, „Wiernośc”, 105-107.

55 Calduch-Benages, En el crisol, 54-55; Calduch-Benages, Un gioiello, 35-36. 
żenia ${ }^{56}$. W tym jednak przypadku Syracydes podaje dokładnie, że chodzi o reakcję

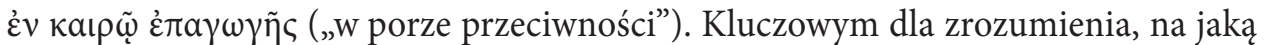

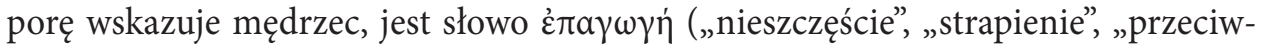
ność"), które rzadko występuje w LXX (por. Pwt 32,36; Iz 10,14; 14,17), ale jest charakterystyczne dla Syracydesa, gdy mówi o zgubnych skutkach złych postaw: pyszałka (Syr 3,38; 10,13), zadufanego w bogactwach (Syr 5,8), przysięgającego fałszywie (Syr 23,11), tego, który nienawidzi (Syr 25,14), i człowieka grzesznego (Syr 40,9). W zasadniczej mierze takie „nieszczęście” jest zawsze, za wyjątkiem Syr 38,19 (nieszczęście wzmagające ból), z wynikiem zła uczynionego przez człowieka ${ }^{57}$. W świetle tego zestawienia trudno jest dokładnie wskazać, o jakiej „porze nieszczęścia” mówi Syracydes w omawianym wersecie $2 \mathrm{G}, 2^{58}$. Najprawdopodobniej wskazuje on na pewien czasokres niedoli naznaczony przeciwnościami, które zadręczają i zasmucają serce człowieka, prowadząc go wprost do zagrożenia życia lub zdrowia. Niedola ta może mieć charakter zarówno duchowy - wewnętrzny (por. Syr 38,19), jak i zewnętrzny (por. Syr 40,9). Z pewnością można tu dostrzec powiązanie z wcześniej-

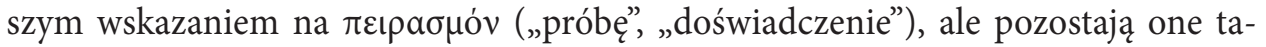
jemnicze. Na podstawie analizy użytych tu słów można powiedzieć, że chodzi o porę naznaczoną cierpieniem z powodu wyrządzonego zła ze strony człowieka lub czasu doświadczenia pochodzącego wprost od Boga ${ }^{59}$. Uczeń jest w ten sposób wezwany, aby w trudnych czasach formować się w cierpliwości. Powinien on nabywać umiejętności oczekiwania na chwile pochodzące od Boga i nie podejmować pośpiesznych decyzji w czasie naznaczonym ciemnością ${ }^{60}$. Syracydes pamięta przy tym, że Bóg może poddać próbie człowieka, ale też daje poznać, jak okazuje się z dalszego kontekstu, że nie sposób rozpoznać trudności życia jako próby i doświadczenia bez zawierzenia Bogu, który zbawia ${ }^{61}$.

56 Piwowar, „Wierność”, 108-109. Cenna jest w tym miejscu uwaga Calduch-Benages (En el crisol, 56), która

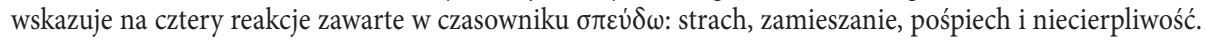
„Strach zmusza człowieka do ucieczki od niekorzystnej sytuacji i unikania niebezpieczeństwa; zamieszanie przysłania i zakłóca spokój umysłu i strąca go w ciemność; pośpieszne działanie, będące wynikiem rozpaczy, natarczywości lub niecierpliwości, prowadzi człowieka do śmierci w czasie i na wieczność; wreszcie niecierpliwa i nietolerancyjna postawa niszczy zaufanie do Boga i otwiera drzwi do przesądów lub innych nieuczciwych rozwiązań. Nie ma nic, co czyni gorszym zło i oddala dobro, jak niepokój i pośpiech".

57 Piwowar, „Wierność”, 108-109.

58 Zdaniem Calduch-Benages (Un gioiello, 38) pewną sugestią może być wspomniany wyżej los człowieka

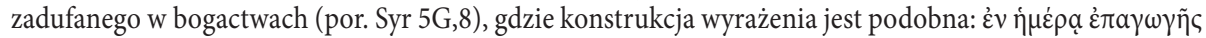
(„w dzień nieszczęścia”). W tekście hebrajskim MsA w tym miejscu pojawia się określenie bardziej precyzyjne: הרבע פויב w dniu gniewu (Boga)" (por. Ez 7,19; Sof 1,18), co mogłoby świadczyć o tym, że grecki tłumacz stonował nieco zbyt ostre wyrażenie o sądzie.

59 Piwowar, „Wierność”, 109-110.

60 Calduch-Benages (En el crisol, 59) dodaje przy tym cytat z XVII-wiecznego komentarza Le Maistre de Sacy, L’Ecclésiastique, 27: „Nie spieszcie się w wychodzeniu ze strapienia, które wygląda jak czas ciemności i mgły. Kto wierzy, ten się nie spieszy, mówi Prorok. Pozostaje tam, gdzie Bóg go postawił, i to mu wystarcza. Konieczność czekania mu nie przeszkadza, ponieważ czeka na Boga i nie czeka na Niego daremnie".

61 Gilbert, „Il concetto”, 89. 
Dla mędrca zbawcze działanie Boga dokonuje się w czasie. Podsumowując swoje zalecenia dane uczniowi na czas doświadczeń (por. Syr 2G,4-9), dla ich zobrazowania odwołuje się do tradycji i zaprasza do dokładnego przypatrzenia się ludziom

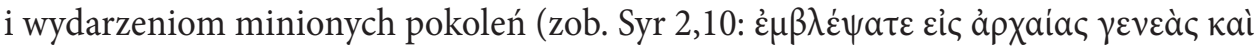
i $\delta \varepsilon \tau \varepsilon)^{62}$. To przywołanie tradycji w samej księdze ma swoją rozbudowaną część w postaci Pochwały ojców (Syr 44-49) $)^{63}$, a w tym miejscu mędrzec zastosował formułę przywołania pytaniami doświadczeń z przeszłości. Gramatycznie stanowią one nie tyle odrębne pytania, co bardziej jedno potrójne pytanie retoryczne (por. Jr 2,14.31; 8,4-5; Mal 2,10; Syr 13,17-18; 18,4-5) ${ }^{64}$. Używając trzykrotnie negacji, mędrzec potwierdza, że niemożliwe jest, aby człowiek wierzący Bogu został oszukany, opuszczony lub porzucony w jego zaufaniu Panu. Czyni to z wyraźnym odniesieniem do postaci z dziejów Izraela ${ }^{65}$, jak też do doświadczeń z własnego życia (zob. Syr $51 \mathrm{G}, 1-12)^{66}$. Kluczowym momentem $\mathrm{w}$ argumentacji mędrca jest jednak zastosowanie tradycji do obecnej sytuacji:

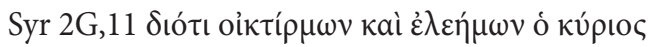

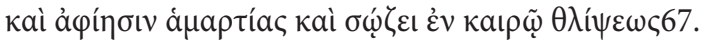

„Dlatego że Pan jest miłosierny i litościwy

I odpuszcza grzechy i ratuje w czasie ucisku ${ }^{68^{\prime \prime}}$.

Jak zostało powiedziane, werset ten zamyka całą strofę odwołującą się do tradycji, podając prawdziwe teologiczne motywy, na których opiera się wezwanie do zaufania Bogu. Prawda o tym, że Pan jest miłosierny i litościwy, znajduje się w kluczowych tekstach ST, bądź jako pełna zdefiniowana formuła (Wj 34,6; Jl 2,13; Jon 4,2; Ps 103,8; 145,8; Ne 9,17), bądź w postaci cząstkowej, dostosowanej do sytuacji (por. Wj 20,5.22.26; Pwt 4,31; Iz 48,9; Ps 78,38; 111,4; 112,4; Ne 9,31; 2 Krn 30,9) ${ }^{69}$. Tekst

62 Zdaniem Calduch-Benages (Un gioiello, 80-83) mamy tu do czynienia z formą ריר ,sporu”, czyli dysputy prawnej, która zawiera trzy etapy: a) wezwanie do przypomnienia tradycji (Syr $2 \mathrm{G}, 10 \mathrm{a})$; b) ponowne odczytanie prawd uznanych w tradycji za pomocą pytań retorycznych (Syr 2G,10bcd); c) zestawienie tradycji z sytuacją lub z aktualnym zagadnieniem i zastosowanie (Syr 2G,11).

63 Pudełko, „Periodyzacja”, 39-76.

64 Calduch-Benages, En el crisol, 130-133.

65 Zdaniem Palmisano (Siracide, 54-55) pytania te odwołują się do przykładów zaczerpniętych z historii (por. Ps 22,5-6; Syr 15G,4b). Trzecie pytanie (Syr 2G,10d) zawiera wyrażenia podobne do tych, które Syracydes używa opisując postacie wysłuchanego wołania: Jozue (Syr 46,5), Samuel (Syr 46,16-17), Dawid (Syr 47,5) i mieszkańcy Jerozolimy za czasów Ezechiasza (Syr 48,20). Szczegółowa analiza tych fragmentów, zob. Demitrów, Quattro oranti, 72-82, 182-194, 285-295, 427-441.

66 Calduch-Benages, En el crisol, 141.

67 Nie zachował się tekst hebrajski, natomiast Syr 2La,11b podaje istotny dodatek wyjaśniający formę zbawienia: et remittit in tempore tribulationis peccata omnibus exquirentibus se in veritate. Natomiast tekst syryjski dodaje: „Wysłucha zawsze i wyzwoli w czasie udręki i wysłucha głos tych, którzy pełnią Jego wolę” (Langkammer, Księga Syracha, 65). 
Syracydesa należy do drugiej grupy, gdyż mędrzec rozwija wyraźnie myśl o miłosierdziu, które przejawia się w mocy odpuszczania grzechów ${ }^{70}$. Ale refleksja mędrca idzie jeszcze dalej, gdy mówi o rzeczywistości zbawienia (czasownik $\sigma \omega \varphi \zeta(\omega)$ ), które pochodzi od Boga (Syr 36,1) działającego przez pośredników (Syr 46,1; Syr 49,10), i jest skierowana ku ludziom sprawiedliwym i bojącym się Pana (Syr 31G,15; 32G,25; 46G,8; $48,20)^{71}$. Uczeń może rozpoznać to boskie pochodzenie zbawienia poprzez osoby i okoliczności egzystencjalne, które towarzyszą uratowaniu człowieka. Te okoliczności nazywa mędrzec „czasem ucisku” (кaıрó $\theta \lambda i \psi \varepsilon \omega \varsigma$ ৎ: por. Syr 22,3; 32G,26; 37,4; 40,24) bądź też „dniem ucisku” (í $\mu \dot{\varepsilon} \rho a$ $\theta \lambda i \psi \varepsilon \epsilon \varsigma$ : 51,10.12), gdy nawet przyjaciel może nie wytrwać w wierności (por. Syr 6G,8.10), ale w których ujawnia się skuteczna boska interwencja w sprawie człowieka czyniącego miłosierdzie (Syr 3G,15). Obie formuły opisują w sposób ogólny sytuację fizycznego lub moralnego niebezpieczeństwa, które powoduje w człowieku stan udręki i głębokiego smutku (por. Ps 3,2;13,3;138,7) ${ }^{72}$.

Do tego argumentu $\mathrm{z}$ tradycji Syracydes dołącza, pod koniec swego dzieła, własne doświadczenie uratowania przez Boga (Syr 51G,1-12) 7 $^{73}$. Czyni to $\mathrm{w}$ formie dziękczynienia, wymieniając całą serię sytuacji, z których został wybawiony: zagłada, sidło oszczerstwa języka, wargi wytwarzające kłamstwo, przeciwnicy (Syr 51G,2), ukąszenie, czyhający na jego życie, mnóstwo ucisków (Syr 51G,3), uduszenie ogniem (Syr 51G,4), głębiny łona otchłani, język nieczysty, wargi kłamliwe (Syr 51G,5), aż po totalne osamotnienie i bliskość śmierci (Syr 51G,7). Te właśnie różnorakie niebezpieczeństwa są w rzeczywistości połączeniem obrazów wyrażających straszne doświadczenie (na poziomie egzystencjalnym) człowieka wystawionego na niebezpieczeństwo śmierci z powodu oszczerstw nieprzyjació $1^{74}$. W tym dramatycznym czasie ucisku uratowało go wspomnienie o miłosierdziu Pana (Syr 51G,8.10) i skierowane do Niego błaganie o uratowanie życia, które zostało wysłuchane (Syr 51G,9-11). W ten sposób, dzięki działaniu Boga, czas strapienia stał się czasem zbawienia. Dla Syracydesa to On jest Panem czasu zaofiarowanego człowiekowi; gdy ten do Niego się zwraca i Jemu do końca zaufa, nawet pośród utrapień doświadczy Jego opieki ${ }^{75}$.

$\mathrm{Na}$ taką interwencję może liczyć człowiek, który odpłaca dobrodziejstwami za

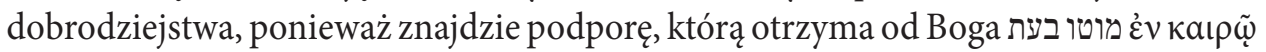
$\pi \tau \dot{\sigma} \sigma \varepsilon \omega \varsigma$ aủंoṽ „W czasie swego potknięcia” (Syr 3,31). Dlatego mędrzec zachęca,

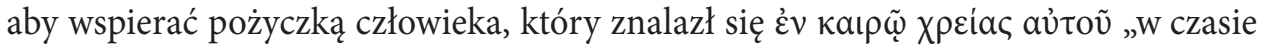

70 Palmisano (Siracide, 55) dodaje ważną uwagę, że w tle przykładów dziejów Izraela szczególnie narzuca się odniesienie do teofanii na Synaju w kontekście odnowienia przymierza po grzechu sporządzenia złotego cielca i oddawaniu mu czci (Wj 34,6-9). Ważny jest fakt, że ta formuła pojawia się w tekstach błagania Boga o przebaczenie (por. Lb 14,19; Ps 25,11), jak również w obietnicach prorockich dotyczących przebaczenia (zob. Jr 31,34; 33,8; 36,3), zob. Calduch-Benages, En el crisol, 143-145.

71 Calduch-Benages, Un gioiello, 94.

72 Calduch-Benages, En el crisol, 145-146.

73 Pełną analizę tej modlitwy, zob. Gilbert, „L’action de grâce”, 231-242.

74 Calduch-Benages, Un gioiello, 95.

75 Calduch-Benages, En el crisol, 147-148. 


\section{ANDRZEJ DEMITRÓW}

jego potrzeby" (Syr 29G,2), ale też zwraca uwagę na dotrzymanie słowa w sprawie

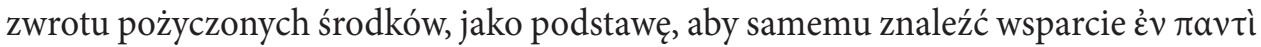

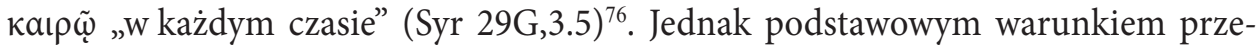
trwania czasu próby jest serce umocnione dojrzałym namysłem, bo w takiej chwili człowiek umocniony nie zdezerteruje (Syr 22G,16). Równocześnie dla Syracydesa

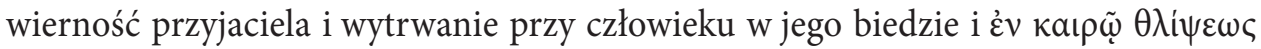
(„w czasie ucisku”) wiążą się z obietnicą przyszłego wspólnego dziedziczenia (Syr 22G,23; por. Mt 5,3-12). Mędrzec zna jednak też ból rozczarowania, gdy osoba uznaבעת צוקה na dotychczas za przyjaciela (Syr 6,8), zmienia swoje nastawienie właśnie

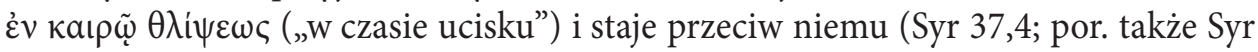
$12 \mathrm{H}, 15-16)$. Specyficzną postacią pory próby jest dla mędrca czas choroby (por. Syr 38,1-15); עת („,czas”), w którym wybawienie człowieka jest w rękach lekarza (Syr 38H,13). Pełny kontekst wypowiedzi Syracydesa wskazuje jednak na aktywną obecność Boga, do którego winien zwracać się w modlitwie zarówno pacjent, jak i leczący go (Syr 38,9-11.14).

Dlatego mędrzec tym bardziej potrafi docenić doświadczenie piękna miłosier-

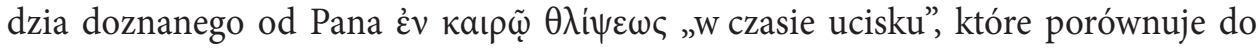
chmur deszczowych w czasie posuchy $(\text { Syr } 35 \mathrm{G}, 24)^{77}$. Jest również przekonany, że doznawane przykrości, które są tak charakterystyczne dla okresu ucisku, będą trwały

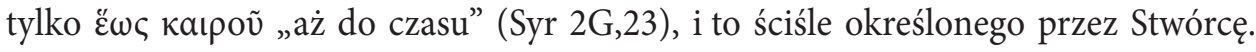
W takich sytuacjach mądrością jest zachowanie powściągliwości w wypowiadanych słowach ह̌ $\omega \varsigma$ кaıрoṽ „aż do czasu” (Syr 2G,24), w którym uspokoi się gniew pod wpływem cierpliwości człowieka roztropnego.

\section{b) czas odpowiedni, aby mówić i aby milczeć}

Syracydes jest głęboko świadomy, że każda sprawa w ludzkim postępowaniu wymaga odpowiedniego momentu. Stąd potrzeba szczególnego rozeznania sytuacji i okoliczności, w które konieczne jest zachowanie czujności (Syr 4,20):

„Synu mój, czasu zgiełku strzeż się i uważaj na zło

i na duszę swoją i nie zawstydzisz się (Syr 4H,20) ${ }^{78}$.

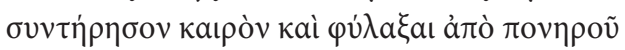

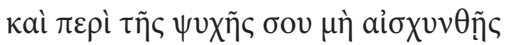

„rozeznaj właściwy czas strzeż się od złego

a z powodu swej duszy nie będziesz się wstydzić” (Syr 4G,20).

\footnotetext{
Palmisano, Siracide, 270-271.

Palmisano, Siracide, 323.

Langkammer, Księga Syracha, 77.
} 
Mędrcowi wyraźnie zależało, aby ustrzec swego ucznia od złego i od sytuacji zawstydzenia. Najbardziej jest to widoczne w sferze języka, kiedy przychodzi spo-

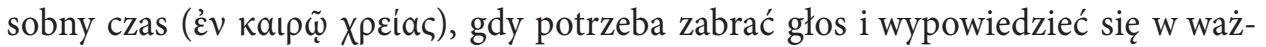
nych sprawach (Syr 4,23), nie kierując się przy tym względami na osoby czy fałszywym wstydem (Syr 4,21-22). Stąd tak istotny jest okres napełniania się mądrością

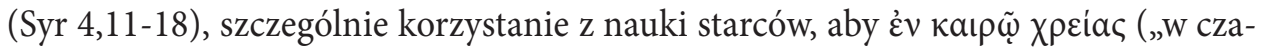
sie potrzeby") udzielić odpowiedzi (Syr 8,9). Są jednak chwile, w których należy się powstrzymać przed mówieniem (Syr 20G,1). Zachowanie milczenia w oczekiwaniu na kaıpóv („czas sposobny”) jest przejawem mądrości (Syr 20G,6-7). Natomiast objawem głupoty i braku wychowania jest wypowiadana sentencja w czasie niestosownym (Syr 20G,19: ä́kaıрoৎ); dlatego, zdaniem Syracydesa, zostanie ona przyjęta przez słuchających ze wzgardą (Syr 20G,20). Brak kontroli nad językiem w tym przypadku grozi zatraceniem, bo nie wystarczy posiadanie wiedzy, którą ktoś się dzieli bez zastanowienia i namysłu, w sposób niedostosowany do chwili ${ }^{79}$. Dla zobrazowania tej prawdy mędrzec używa mocnego porównania o podłożu egzystencjalnym: „czym muzyka w żałobie, tym opowiadanie nie w porę (åkaıрoৎ)", natomiast każdą porę

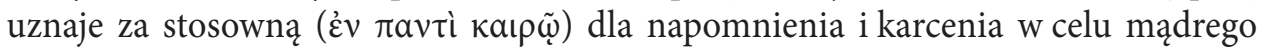
wychowania młodego pokolenia (Syr 22G,6).

Szczególną przestrzenią „doświadczalną” w tym aspekcie są dla Syracydesa uczty i biesiady (por. Syr 31,12-24) ${ }^{80}$. Obecność przy stole zależy w dużej mierze od towarzyszących osób, stąd konkretna rada mędrca, aby skracać kaıpóv („czas”) przebywania wśród nierozumnych, a raczej wydłużać go w towarzystwie mędrców (Syr 27G,12). Mędrzec zna niebezpieczeństwo nadużywania wina podczas uczt, dlatego radzi zachować umiar w jego ilości i rozeznanie, co do $\dot{\varepsilon} v$ kaıрụ („właściwego czasu"). Celem tych porad, danych uczniowi, jest jednak pozytywne nastawienie,

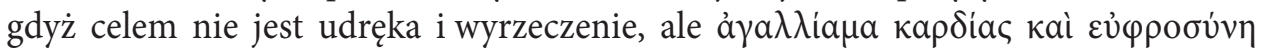
భvхñ („zadowolenie serca i radość duszy”) (Syr 31G,28). Udział w uczcie staje się swoistą weryfikacją roztropności i mądrości ucznia, zarówno w kwestii zabierania głosu w odpowiednim czasie $(\operatorname{Syr} 32 \mathrm{H}, 4)^{81}$, jak i powrotu w stosownej porze z biesiadowania do domu (Syr 32H,11).

\subsection{Czas jako pora Bożych interwencji}

Już w dotychczasowych analizach niemal w każdym fragmencie, w którym pojawiało się odniesienie do rzeczywistości opisanej słowem kaıpóৎ „czas”, można było zauważyć odniesienie do Boga - nieraz dyskretne i ukryte - jako Stwórcy panującego nad czasem. Nie brakuje jednak bezpośrednich odniesień do Pana

\footnotetext{
79 Langkammer, Księga Syracha, 172.

80 Palmisano, Siracide, 287-291.

81 Zob. analizę tego fragmentu: Gilbert, „N'empêche pas la musique!”, 699-706.
} 


\section{ANDRZEJ DEMITRÓW}

władającego całą rzeczywistością, zarówno kosmosem, jak też biegiem historii indywidualnej i społecznej. Dla mędrca Bóg czuwa nad wszystkim, także wobec sprawujących władzę.

ביד אלהים ממשלת תבל

ואיש לעת יעמד עליה משלת תבים

„W ręku Boga władanie nad wszystkim,

i człowiek właściwy na ten czas stanie nad nią" $(\text { Syr } 10 \mathrm{H}, 4)^{82}$.

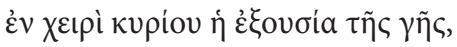

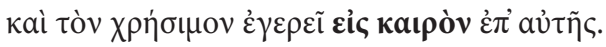

„W ręku Boga władza ziemi

I właściwego (człowieka) podniesie na dany czas nad nią" (Syr 10G,4).

To odważne stwierdzenie Syracydesa, który relatywizuje w ten sposób uzurpacje władców przypisujących sobie tylko zdobycie panowania nad innymi ${ }^{83}$. To Bóg jest tym, który wybiera i wzbudza to, co konieczne w określonym momencie historii (por. Prz 8,15-16; Mdr 6,24; Iz 11,2-5; Jr 27,5; Dn 2,21; Rz 13,1). W perspektywie mądrościowej właśnie Bóg kieruje biegiem historii i dziejami narodów, działając tak, aby był podtrzymany ład społeczny przez Niego ustanowiony ${ }^{84}$. Kontekst tej sentencji jest wyraźnie polemiczny względem władców nierozumnych i władających przez niesprawiedliwość, przemoc i chciwość (Syr 10,1-8), co najprawdopodobniej wypływa z osobistych doświadczeń Syracydesa czasu przejęcia panowania Ptolomeuszy nad Palestyną przez Seleucydów ${ }^{85}$.

\subsection{Czas w aspekcie ustalonego kresu}

Mędrzec jest świadomy tej szczególnej władzy Boga nad światem, dlatego kieruje rozbudowane błaganie do Stwórcy o ocalenie miasta świętego, Jeruzalem i ludu wybranego (Syr 36H,1-17) ${ }^{86}$. Ta modlitwa zawiera wyraźną prośbę o Bożą interwencję w obliczu najazdu nieprzyjaciół:

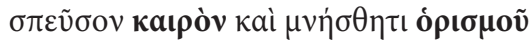

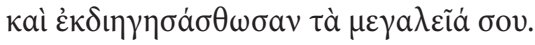

82 Palmisano, Siracide, 118.

83 Sauer, Jesus Sirach, 105.

84 Palmisano, Siracide, 118.

85 Langkammer, Ksiegga Syracha, 107. Antioch III odniósł zwycięstwo nad Ptolomeuszem V pod Paneas (198 r. przed Chr.), a Palestynę przekazał Seleucydom (por. Dn 11,10-19). Okrucieństwa władzy nowych rządów nie oszczędzały nawet Świątyni Jerozolimskiej. Zob. też Palmisano, Siracide, 119.

86

Palmisano, Siracide, 324-329. Pełna analiza tej wspaniałej modlitwy, jak również wyjaśnienie istniejących różnic pomiędzy tekstem hebrajskim i greckim, zob. Palmisano, Salvaci, 129-321. 
„Przyśpiesz czas i pamiętaj na koniec

I niech będzie opowiadana wielkość Twoja" (Syr 36G,7) ${ }^{87}$.

Tekst hebrajski tej modlitwy nie zawiera typowego terminu ע, natomiast wprowadza oryginalne słownictwo z obszaru chronologii:

כי מיש קי ופקוד מועד לך מה תעשה

„Przyśpiesz koniec i wspomnij na czas ustalony,

Ponieważ kto mógłby Ci powiedzieć: «Co czynisz»?” (Syr 36H,10).

Istotne dla zrozumienia przesłania tej prośby jest zestawienie dwóch terminów:

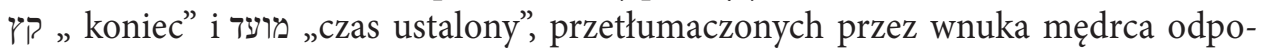

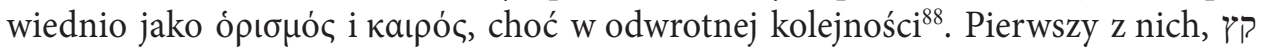
„koniec”, pojawia się często u Syracydesa w kontekście kultycznym, ale także w znaמועד czeniu „kresu”, „granicy” (por. Syr 41H,4a; 43H,6b; 46H,19) „czas ustalony”, oprócz kontekstu kultycznego, odnosi się także do wyznaczonych momentów i pór czasowych (por. Syr 31H,19a; 33H,8b; 43H,7a; 50H,6b.8a) ${ }^{90}$. Ich paralelne zestawienie, występujące często w późniejszych: Księdze Daniela $(9,26)$ i pismach z Qumran (1QM XI 8; 1QH ${ }^{a}$ VI 29-30), przejmuje odcienie znaczeniowe czasowe bądź eschatologiczne ${ }^{91}$. Kontekst modlitwy mędrca wskazuje na zbliżający się „dzień Pana” (por. Syr 36H,7), znany w tekstach prorockich jako dzień ostateczny, powszechnego zniszczenia i katastrofy (por. Ez 7,2.6-8; zob. też Rdz 6,13). Jednocześnie należy podkreślić odcień znaczeniowy czasu, uwyraźniony w tekście greckim przez słowo kaıpós. Oba wymiary służą ukazaniu działania Bożego w obecnym czasie, który jest zdolny wyznaczyć nowy i decydujący kierunek biegowi wydarzeń, kładąc „kres” doznawanej wcześniej przemocy (por. Dn 8,19; 11,27.35) ${ }^{92}$.

Na szczególną uwagę w temacie Bożych interwencji w czasie zasługuje zapowiedź przyszłej działalności proroka Eliasza, o której pisze Mędrzec w podsumowaniu jego misji (por. Syr 48H,1-11) ${ }^{93}$ :

\footnotetext{
87 Warto w tym miejscu zauważyć różnice w rękopisach greckich, które zostały uwzględnione w wydaniach

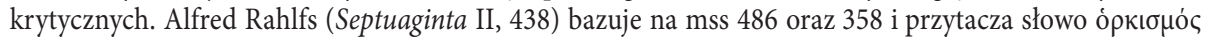
„przysięga”. Natomiast Joseph Ziegler (Sirach, 290), idąc za Vetus Latina i wersjami syriackimi, koryguje ten wyraz na ó

88 Zdaniem Palmisano (Salvaci, 189) podobne zjawisko odwrócenia można spotkać częściej w tekście greckim Syracydesa (por. Syr 33G,9; 46G,19).

89 Wagner, „ק?", THAT II, 659-663.

90 Koch, „מוֹעָ", ThWAT IV, 744-750

91 Palmisano, Salvaci, 214, przyp. 117 i 118.

92 Palmisano, Salvaci, 216-217.

93 Szczegółową analizę tego fragmentu prezentuje Ralph Hildesheim (Bis daß ein Prophet) 64-104.
} 
„Jak jest napisane, przygotowany na czas określony,

aby uspokoić gniew przed [...],

aby zwrócić serce ojców ku synom

i przywrócić [plemiona Izraela]" (Syr 48H,10) ${ }^{94}$.

Wersja grecka różni się od hebrajskiej, stosuje nieco odmienną koncepcję czasu w liczbie mnogiej:

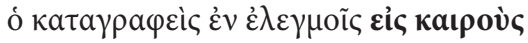

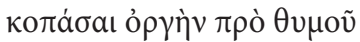

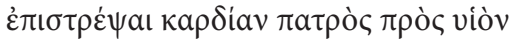

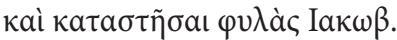

„opisany w karceniach na czasy (przyszłe),

by uspokoić gniew przed pomstą,

by zwrócić serce ojca do syna

I odnowić pokolenia Jakuba" (Syr 48G,10).

W swej treści werset ten odwołuje się do proroctwa Malachiasza: „Oto Ja posyłam dla was Eliasza proroka przed obliczem nadchodzącego dnia Pana, wielkiego i strasznego. I zwróci serce ojców do synów, a synów do ich ojców, abym nie przyszedł

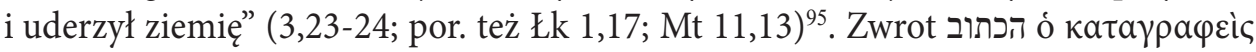
(„jak jest napisane”) świadczy o szczególnym uszanowaniu tych słów i uznaniu ich za święte i natchnione ${ }^{96}$. Mędrzec wyraźnie postrzega Eliasza jako człowieka przewidzianego ku przestrodze przyszłych pokoleń przed nadejściem dnia Pańskiego. Na podstawie wyżej omawianego tekstu Syr 36H,7 można powiedzieć, że mędrzec specyficznie pojmuje ten moment jako przywracającą sprawiedliwość interwencję Boga w dzieje ludzi (Syr 36H,6-10)97; stąd najprawdopodobniej w tym kluczu należy odczytać Syracydesową interpretację prorockiego tekstu Mal 3. Wyrażenie לעת „na czas określony” wskazywałoby na poprzedzający sam dzień Pana proces pojednania i pokonania konfliktów międzypokoleniowych, naznaczonych grzechem ludu, jak na to wskazuje druga część wersetu przez odniesienie do „plemion Izraela/Jakuba”

94 Według Palmisano (Siracide, 462) brakujące końcówki stychów można wiarygodnie zrekonstruować na podstawie rękopisów syriackich: „przed nadejściem dnia Pana” i „plemiona Izraela”; por. Calduch-Benages - Ferrer - Liesen, La Sabiduría, 256.

95 Kuśmirek, Prorocy, 1571; Maertens, Léloge, 183.

96 Skehan - Di Lella, Wisdom of Ben Sira, 534; Langkammer, Księga Syracha, 411.

97 Hildesheim, Bis daß ein Prophet, 101. 
$(\text { Syr 36H,10 })^{98}$. Niektórzy badacze zastanawiają się jednak nad eschatologicznym czy też apokaliptycznym znaczeniem tego wyrażenia ${ }^{99}$. Termin ten jednak, obecny już Księdze Izajasza (49,6), wskazywałby bardziej na nadzieje mesjańskie, których spełnienie zagwarantował sam Bóg (por. Syr 47,11.22) ${ }^{100}$. Faktycznie dla mędrca proroctwo jest swego rodzaju żywym zaczynem, który nadal działa w dziejach, fermentując je i ożywiając wciąż na nowo ${ }^{101}$. W tle pozostaje najgłębsze przekonanie, że do Boga należy wyznaczenie właściwej pory i czasu spełnienia się obietnic.

\subsection{Czas Bożego błogosławieństwa i odpłaty}

Syracydes jest w pełni świadomy, że całe życie człowieka, czy w bogactwie, czy w ubóstwie, toczy się pod wyraźnym Bożym prowadzeniem, którego konkretnym przejawem jest w życiu rodzinnym osoba dobrej małżonki, wprowadzającej pogodę

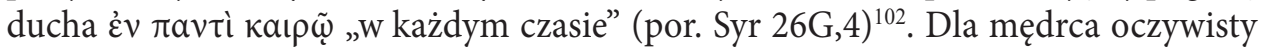
jest fakt, że Bóg ujmuje się za człowiekiem prawym w darze pomyślności.

„Błogosławieństwo Pana dla stóp sprawiedliwego

i w odpowiednim czasie jego nadzieja zaoowocuje” (Syr 11H,22).

Tekst G różni się nieco od $\mathrm{H}$, kiedy w miejsce „czasu” wprowadza „godzinę”:

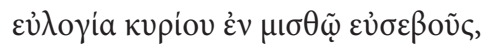

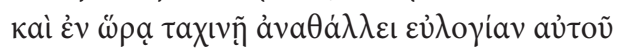

„Błogosławieństwo Pana nagrodą pobożnych

i w godzinie bliskiej tryśnie błogosławieństwo jego"103.

W podobnej perspektywie, ale z wyraźniejszym akcentem postawionym na Bożą odpłatę, Syracydes przestrzega przed zuchwałym postępowaniem wobec Pana. Dla mędrca szczególnym czasem Bożej interwencji jest moment śmierci, jako chwili rozliczenia z tego, co wydarzyło się w ciągu życia człowieka. Stąd szczególne napomnienie dotyczące postawy wobec Boga, aby nie zwlekać ze sprawą nawrócenia: drzec wyraża życzenie, aby Izrael ponownie objął w posiadanie ziemię, według patriarchalnych obietnic.

99 Hildesheim, Bis daß ein Prophet, 103-107.

100 Skehan - Di Lella, Wisdom of Ben Sira, 534; Petraglio, Il libro, 296.

101 Palmisano, Siracide, 463.

102 Langkammer, Księga Syracha, 214.

103 Wojciechowski, Księgi greckie, 543. 
אל תאחר לשוב אליו ואל תתעבר מיום ליום כי פתאום יצא זעמו ובעת נקם תספה תאיובה מיום

„Nie odwlekaj nawrócenia do Pana i nie odkładaj z dnia na dzień;

gdyż nagle wyjdzie gniew Jego i w czasie pomsty będziesz zabrany" (Syr 5H,7) ${ }^{104}$.

Tekst grecki zawiera pewne różnice godne zauważenia:

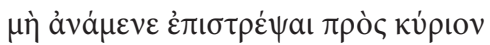

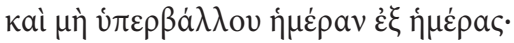

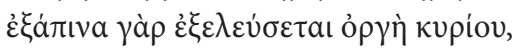

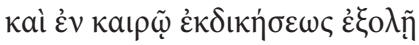

„Nie zwlekaj nawrócić się do Pana

i nie przerzucaj dzień po dniu.

Znagła bowiem przyjdzie gniew Pana

i w porze pomsty zginiesz" (Syr 5G,7) ${ }^{105}$.

Kontekstem tak wyraźnego napomnienia jest styl życia, w którym posiadane bogactwa dają poczucie zabezpieczenia (Syr 5,1), i złudne przekonanie o bezkarnym postępowaniu według żądz i chwilowych zachcianek (Syr 5,2-3), bez liczenia się z Bogiem, a wręcz w postawie zuchwałego grzeszenia w oczekiwaniu na miłosierdzie (Syr 5,4-6) ${ }^{106}$. Stąd przestroga, aby taki człowiek nie odkładał w czasie momentu nawrócenia, bo w przeciwnym razie doświadczy skutków swojej postawy w postaci gniewu Bożego i śmierci w בעת נקם („w czasie pomsty”). Określenie נקם („pomsta”) występuje najczęściej w odniesieniu do wrogów ludu wybranego (por. Syr 35H,22d/ $32 \mathrm{G}, 23 \mathrm{a})$, których postępowanie zostanie osądzone przez Boga $(\mathrm{Syr} 46 \mathrm{H}, 1)^{107}$. W takiej pozycji staje także człowiek, gdy będąc członkiem narodu wybranego w przymierzu z Bogiem (por. Syr 48H,7), swoim postępowaniem zaprzecza tej najgłębszej więzi miłości ze Stwórcą i Panem ${ }^{108}$. Bóg pozostaje zawsze jedynym i najważniejszym obrońcą tej więzi i strażnikiem prawa do życia każdego człowieka. Gdy to prawo jest przekraczane, to właśnie Bóg בעת נקם („w czasie pomsty”) wymierzy sprawiedliwość temu, który je przekracza ${ }^{109}$. Mędrzec ewidentnie odnosi się do momentu śmierci, który traktuje jako chwilę odpłaty za popełnione czyny (por. Syr 7,17; 11,26-27; $17,24-18,14)^{110}$. Jak wynika $\mathrm{z}$ analiz tekstów przedstawionych wyżej, jedynie Bóg zna

\footnotetext{
104 Langkammer, Księga Syracha, 80.

105 Wojciechowski, Księgi greckie, 518.

106 Palmisano, Siracide, 78-80.

107 Lipiński, „נקם", ThWAT V, 610-611; Peels, Vengeance, 86-92; Sauer, „נקם", THAT II, 106-109.

108 Według Jana Liesena (Full of Praise, 268-269) wyrażenie נקם odzwierciedla reakcję Boga wobec Jego wrogów i tych, którzy przeciwstawiają się ludowi jego przymierza; zob. także Peels, Vengeance, 91.

109 Demitrów, Quattro oranti, 53.

110 Palmisano, Siracide, 80; Langkammer, Księga Syracha, 80.
} 
ten moment, a Jego cierpliwość względem człowieka wynika z miłosierdzia, które oczekuje na postawę nawrócenia.

Wymowny pozytywny przykład Bożej odpłaty pojawia się w punkcie finalnym Księgi Syracydesa, w którym mędrzec podsumowuje swoje życie (por. Syr 51,13-30). Swoje wspomnienia z całości życia wieńczy wezwaniem do zaangażowania się na drodze zdobywania nauki, która jest równa złotu i srebru, a przynosi poczucie radości i szczęścia (Syr 51H,28-29), pod warunkiem jednak zaangażowania w trud i pracę w aktualnym czasie:

„Dzieła wasze wykonujcie w sprawiedliwości

A On da wam zapłatę waszą w swoim czasie" (Syr 51H,30) ${ }^{111}$.

Tekst grecki przedstawia się w nieco odmiennej formie:

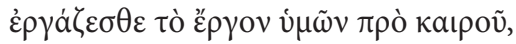

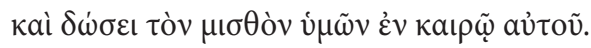

„Wykonujcie dzieło wasze przed czasem,

i (On) da zapłatę waszą w swoim czasie" (Syr 51G,30 $)^{112}$.

O ile tekst H kładzie nacisk na pełnienie czynów בצדקה („w sprawiedliwości”) jako niezbędny warunek rekompensaty w odpowiednim czasie, o tyle tekst G dwukrotnie podkreśla rolę czasu w podjętym dziele zdobywania mądrości ${ }^{113}$. W obu wersjach wezwanie to stanowi otwarte ku przyszłości zwieńczenie całej księgi i zawiera wezwanie do wypełnienia dzieła $\pi \rho$ ò кaıрoũ („przed czasem”) w oczekiwaniu

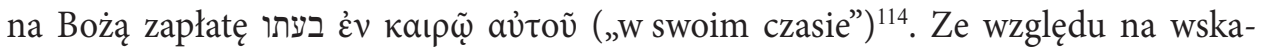
zaną przez mędrca perspektywę Boga, dawcy wszystkich darów, nie można wykluczyć w tym miejscu wydźwięku eschatologicznego, w którym „Bóg zmierzy «czas» rozpoczęcia życia po Bożemu ze «swoim czasem» obiecanej nagrody"115. Nie jest to wprawdzie zapłata natychmiastowa, ale za to pewna spełnienia w jej oczekiwaniu.

111 Końcowy fragment tego wersetu znajduje swoje potwierdzenie w Qumran (11Q5): ותעב םכרכש (...) ,zapłatę waszą w swoim czasie"; Beentjes, The Book, 178.

112 Palmisano, Siracide, 504-505; Langkammer, Księga Syracha, 451. Por. też Wojciechowski, Księgi greckie, 709: „Wykonajcie dzieło wasze przed porą, i da zapłatę waszą w porze jego”.

113 Powiązanie czynów ze sprawiedliwością (צדקה) podkreśla jeszcze bardziej ukierunkowanie nauczania mądrości na Boga: Sauer, Jesus Sirach, 351. Langkammer (Księga Syracha, 451) sugeruje, że tym wyrażeniem mędrzec być może wprowadza myśl o sądzie ostatecznym.

114 Liesen, Full of Praise, 136, przyp. 115; Palmisano, Siracide, 504.

115 Zapff, Jesus Sirach, 399; Langkammer, Księga Syracha, 451. Innego zdania jest Gilbert („Il concetto”, 88), który dostrzega w tym miejscu przyszłą nagrodę, ale nie o charakterze eschatologicznym. 


\subsection{Odpowiedni czas przewidziany przez Boga dla wszystkich zdarzeń}

Do fragmentów księgi, w których termin „czas” pojawia się najczęściej, należy tzw. „Hymn na cześć Stwórcy” (Syr 39,12-35). Można wyróżnić w nim trzy sekcje: wezwanie mędrca do uwielbienia Boga (Syr 39,12-15), właściwy hymn mędrca (Syr 39,16-31) i końcowa refleksja z elementem autobiograficznym (Syr 39,32-35) ${ }^{116}$. Środkowa część hymniczna zawiera trzy wyraźnie odróżniające się strofy: w pierwszej Syracydes uwielbia Boga za piękno Jego dzieł w aspekcie stworzenia i odkupienia (39,16-21); w drugiej - przedstawia swoiste antytezy działania Boga względem wiernych i względem grzeszników $(39,22-27)$; w trzeciej - podaje spis zjawisk stworzonych, które służą karze Bożej $(39,28-31)^{117}$. Termin „czas” występuje w części hymnicznej, w strofie pierwszej strofie $(39,16.21)$ i trzeciej $(39,28.31)$ oraz w zakończeniu (39,33-34), podkreślając tym samym szczególne znaczenie, które Mędrzec wiąże $\mathrm{z}$ koncepcją czasu ${ }^{118}$.

Początek części hymnicznej wyznacza kierunek myśli mędrca:

[עשי[ אל כלם טובים] וכל צורך בעתו יספיק

„[Dzieła] Boga wszystkie one są dobre

I wszystko co potrzebne, w swoim czasie zapewnia" (Syr 39H,16).

Tekst G jest nieco dłuższy i rozwija podaną myśl w postaci pytania retorycznego:

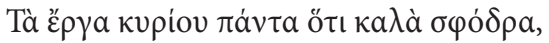

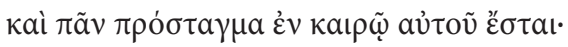

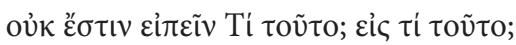

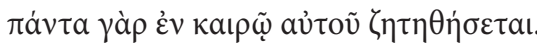
„Dzieła Pana wszystkie, że są bardzo piękne I wszelki rozkaz w swoim czasie będzie.

Nie można mówić: «Co to?» «Po co to wszystko?»

Wszystko bowiem w swoim czasie będzie zbadane" (Syr 39G,16) ${ }^{119}$.

Zasadnicze przesłanie hymnu zawiera się nie tylko w uznaniu wszystkich dzieł

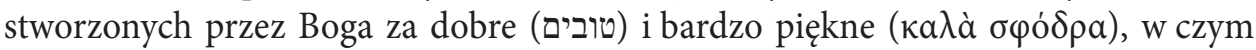

116 Liesen, Full of Praise, 25-30. Godna uwagi jest cała pozycja tego autora, która w całości jest poświęcona Syr 39,12-35.

117 Palmisano, Siracide, 356-362.

118 Gilbert, „Il concetto”, 82. Liesen (Full of Praise, 96) zauważa, że dwa wersety (Syr 39H,33.34) w części wieńczącej hymn stanowią powtórki dwóch wcześniejszych wersetów, które rozpoczynają i kończą pierwszą strofę: 39H,33 powtarza 39H,16, a 39H,34 podejmuje treść wersetu 39H,21cd.

119 Rahlfs, Septuaginta, II, 445; Wojciechowski, Księgi greckie, 655. 
Syracydes nawiązuje do Księgi Rodzaju (1,4.10.12.18.21.25.31). Mędrzec idzie dalej i dołączamotyw Opatrzności Bożej, która wyraża się działaniem בעתו „we właściwym

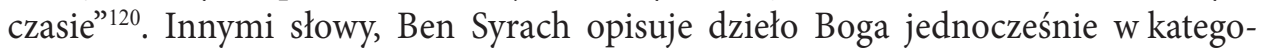
riach stworzenia i zbawienia, czyli podtrzymania przy życiu. Podkreśla także, że Bóg czuwa nad każdym ludzkim dziełem, a zatem jest ono zarazem Bożym dziełem, które dokonuje się nie tylko w czasie, ale też zawsze we właściwej, odpowiedniej porze ${ }^{121}$.

Ten aspekt zbawienia, dokonującego się w czasie, znajduje się w centrum uwagi hymnu, który następnie autor rozwija poprzez aluzje do dzieła stworzenia (Rdz 1,9), ale też do przejścia przez Morze Czerwone i przez rzekę Jordan (Syr 39,17; por. Wj 14,21; Joz 3,14-16). Stwórczemu rozkazowi Boga towarzyszy nie tylko zaistnienie, ale stała pomoc i czuwanie Boga nad stworzeniami, szczególnie nad człowiekiem, wyrażone w antropomorficznym motywie oczu i spojrzenia (Syr 39,18-20) ${ }^{122}$. Mówiąc inaczej, pomoc Boża nie jest tylko doraźna, ale ciągła (providentia continua), i nie dotyczy stworzenia w ogólności, ale sięga po każdy byt i osobę, przechodzi od wieczności w czas ${ }^{123}$.

Na zakończenie pierwszej strofy pojawiają się ponownie pytanie semiretoryczne i odpowiedź mędrca:

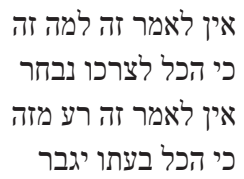

„Nie mów: «Co to? «Po co tamto?»,

ponieważ wszystko wybrał dla swego celu.

Nie mów: «To jest gorsze od tamtego»,

ponieważ wszystko w swoim czasie zapanuje" (Syr 39H,21) $)^{124}$.

Tekst G jest w tym miejscu krótszy:

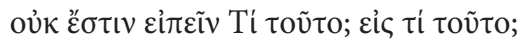

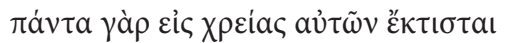

„Nie można powiedzieć: «Co to?» «Dlaczego to?»

Wszystko bowiem stworzył dla ich potrzeb” (Syr 39G,21).

120 Langkammer, Księga Syracha, 317.

121 Według Liesena (Full of Praise, 275) temu też służą semiretoryczne pytania mędrca, na które sam udziela odpowiedzi.

122 Pomoc ma w tym miejscu znaczenie ocalenia i zbawienia. Można powiedzieć, że działając w czasie Bóg nadał dziełu stworzenia znamię soteriologiczne (Syr 39H,18: לתשועתו „dla jego zbawienia”), por. Skehan Di Lella, Wisdom of Ben Sira, 459.

123 Palmisano, Siracide, 358; Langkammer, Księga Syracha, 318.

124 Palmisano, Siracide, 359. 


\section{ANDRZEJ DEMITRÓW}

Zdaniem Marii C. Palmisano dłuższa wersja H może się tłumaczyć przesunięciem dwóch stychów z Syr 39,16, które są obecne w wersji G.

Widać wyraźnie w postawionych pytaniach i udzielanych odpowiedziach, że zdaniem mędrca, wszechmoc i wszechwiedza Boga gwarantują mądry ład stworzenia. To stanowi fundament argumentu Syracydesa, na bazie którego rozważa dobroć aktu stworzenia $\mathrm{w}$ aspekcie czasu ${ }^{125}$. W tym jednak wersecie mędrzec mówi o czasie w kontekście relacji pomiędzy dobrocią dzieła Bożego a jego przydatnością i celowością, w znaczeniu „odpowiedniego momentu”. Warto zaznaczyć, że w tle przytaczanych pytań i obiekcji ukazuje się postawa, na której tak bardzo zależy Syracydesowi i do której wezwany jest człowiek w swej wolności: uszanować intencję Stwórcy i Jego mądrość ${ }^{126}$.

W dalszej części hymnu mędrzec rozwija tę myśl, ukazując dobroć błogosławieństwa rzeczy stworzonych dla człowieka (Syr 39,22.26), w przeciwstawieniu do losu "narodów wypędzonych" z powodu popełnianego zła (Syr 39,23). Stawia przy tym na pozór kontrowersyjną tezę, że rzeczy stworzone jako dobre, ostatecznie obrócą się przeciw ludziom popełniającym zło (Syr 39,25b.27b). Tak sformułowane zestawienia antytetyczne, odczytane w świetle tekstu Syr 15,11-20, który mówi o ludzkiej wolności, prowadzi do zrozumienia, że podział na wiernych i niegodziwych jest konsekwencją wolnego wyboru człowieka ${ }^{127}$.

W trzeciej części hymnu Syracydes podnosi szczególny problem - ukazuje groźne zjawiska przyrody jako stworzenia, które mają służyć ukaraniu winnych (Syr 39,28-31) ${ }^{128}$. Na pierwszym miejscu są wymienione wichry, jako narzędzia sądu, pomsty i gniewu Bożego, przewidziane, aby בעת כלה חילם ישפכו, w czasie zniszczenia wylały swą moc" (Syr 39H,28). Tekst grecki zawiera interesujące tłumaczenie: $\dot{\varepsilon} v$

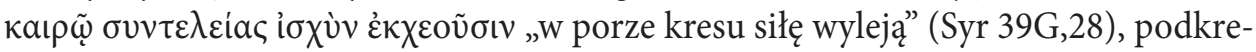
ślające wymiar sądu ostatecznego ${ }^{129}$.

Następnie wymienia ogień, głód i śmierć, jako narzędzia pomsty (Syr 39,29) ${ }^{130}$, oraz dzikie zwierzęta, takie jak skorpiony i żmije, a także miecz, jako narzędzie wojny wobec ludzi złych (Syr 39,30ab). Ten katalog Syracydes wieńczy stwierdzeniem o ko-

125 Liesen, Full of Praise, 245.

126 Gilbert, „Il concetto”, 83.

127 Palmisano, Siracide, 360.

128 Gilbert, „Il concetto”, 84. Zdaniem Marii C. Palmisano (Siracide) 361, sam tekst, przywołując takie elementy teofanii jak wicher i ogień, stanowi wyraźnie aluzję do Pwt 32,22-25; Jr 29,17-18; Ez 5,16-17; Ps $18,8-13 ; 148,8-10$.

129 Wojciechowski, Ksieggi greckie, 657.

130 Warto zauważyć, że w przypadku dziejów ludu Izraela gradobicie przejmuje znaczenie sądu Bożego, który ujawnia się wobec nieprzyjaciól, zwłaszcza w opisie plag w Egipcie (por. Wj 9,18-34; Ps 78,47-48; 105,32; Mdr 16,16.22; Syr 43H,15). Syracydes nawiązuje do tego opisując dzieje Jozuego i momentu zwycięskiej bitwy pod Gabaonem (por. Syr 46H,5-6); Demitrów, Quattro oranti, 80. 


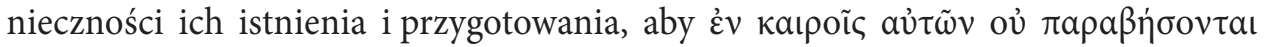

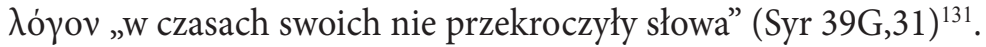

Bazując na dotychczasowych wyjaśnieniach, jest zasadnym stwierdzenie, że dla Syracydesa pewne dzieła Boże i niektóre Jego stworzenia są przewidziane, aby uczestniczyć w karzącym działaniu ludzi wyrządzających zło, „w czasie zniszczenia”, jako wyraz sądu Bożego. Także dzikie zwierzęta czy śmiercionośny miecz są w gotowości, aby interweniować, kiedy to będzie konieczne, to znaczy „w czasie właściwym”, by ukarać winnych. Choć tego typu wniosek wydaje się należeć do języka eschatologicznego, to raczej bardziej zasadne jest przyjęcie tezy, że mędrzec odwołuje się do pewnych faktów, wydarzeń i zjawisk możliwych w przyszłości, które będą powtórzeniem strasznych wydarzeń minionych dziejów Izraela czy innych narodów, jako wyraz przywrócenia sprawiedliwości przez ukaranie $z^{132}$.

W końcowej refleksji Syracydes jeszcze raz powraca do myśli wypowiedzianych na początku hymnu (Syr 39,16), że Bóg wszystko dobrze uczynił i we właściwej go-

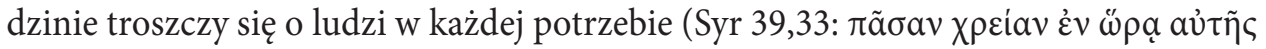

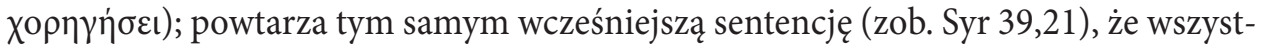

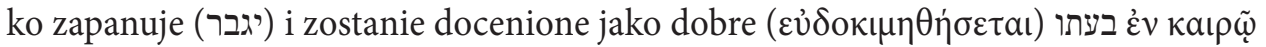
„we właściwym czasie” (Syr 39,34). Po takim przypomnieniu, typowym dla nauczyciela mądrości, mędrzec wzywa do uwielbienia i błogosławienia imienia Boga z całego serca, jako owoc przyswojonej przez ucznia prawdy.

\section{Podsumowanie}

Przyglądając się koncepcji czasu w Księdze Syracydesa, na podstawie występowania terminu кaıрó ( „czas”), jako greckiego tłumaczenia hebrajskiego słowa עת, oraz terminów מועד i „konieczas ustalony”, można zauważyć, że w bogactwie mądrościowego nauczania dominuje przede wszystkim stałe odniesienie do Boga jako Stwórcy. Nie brakuje tekstów, w których to odniesienie pozostaje jedynie w tle, jak na przykład w regułach zachowania przy stole (Syr 31-32). Dla Syracydesa każda czynność jest mierzona słuszną miarą i roztropnością, która zakłada moment rozeznania właściwej pory i odpowiedniego działania. W różnorodności życiowych sytuacji, w jakich znajduje się człowiek, szczególna uwaga mędrca kieruje się na chwile trudne, pełne przeciwności doświadczeń. Także w tym przypadku podejście mędrca cechuje postawa wiary w Boga, który nie opuszcza człowieka, ale towarzyszy mu w jego utrapieniach (Syr 2,1-11). Syracydes daje o tym świadectwo w przejmującej

131 Wojciechowski, Księgi greckie, 657. Tekst hebrajski, zarówno w rękopisie B, jak też w rękopisie z Masady, zachował się w tym miejscu niekompletny; Liesen, Full of Praise, 216-217.

Gilbert, „Il concetto”, 84-85. 


\section{ANDRZEJ DEMITRÓW}

modlitwie dziękczynnej (Syr 51,1-12), w czym też jest bardziej wiarygodny jako nauczyciel spraw, które sam przeżył.

Dla mędrca nie jest więc to jedynie termin wyznaczający chwile życia człowieka: moment zaśnięcia i wstania ze snu, dni, miesiące i lata, także czas odejścia z tego świata, choć takie rozumienie nie jest mu obce. Zadaniem Syracydesa czas jest do wypełnienia poprzez mądre i prawe życie, które sam podjął i pozwolił innym doświadczać poprzez przekaz zdobytej mądrości (Syr 51,13-30). Mędrzec wie, że wszystko zawdzięcza Bogu, któremu nauczył się wierzyć i ufać, że wszystko istnieje „we właściwym czasie”. To ukierunkowanie na Boga najpełniej wybrzmiewa w tekstach, które ukazują wręcz teologię czasu, gdy Syracydes wiąże dzieło stworzenia z podtrzymywaniem go w istnieniu i stałą opieką nad człowiekiem i całym światem stworzonym (Syr 39,12-35). Działanie Boga, który zbawia człowieka „w odpowiednim czasie", stało się dla mędrca sposobnością do wyznania wiary i świadectwa o niej dla przyszłych pokoleń, nie tylko własnego narodu wybranego, ale też dla tych, którzy przez Nowe Przymierze zostali wszczepieni do Ludu Bożego.

\section{Bibliografia}

Argall, R.A., 1 Enoch and Sirach. A Comparative Literary and Conceptual Analysis of the Themes of Revelation, Creation and Judgment (Society of Biblical Literature. Early Judaism and Its Literature 8; Atlanta, GA: Scholars Press 1995).

Bazyliński, St., Wprowadzenie do studium Pisma Świętego, wyd. 2 (Kielce: Jedność 2019).

Beentjes, P. C., „Inverted Quotations in the Bible. A Neglected Stylistic Pattern”, Biblica 63 (1982) 506-523.

Beentjes, P.C. (red.), The Book of Ben Sira in Hebrew. A Text Edition of All Extant Hebrew Manuscripts and a Synopsis of All Parallel Hebrew Ben Sira Texts, wyd. 2 (Supplements to Vetus Testamentum 68; Leiden - New York - Köln: Brill 2003).

Bielecki, S., „Nowotestamentalne ujęcie terminu Kairos”, Ruch Biblijny i Liturgiczny 45/2-6 (1992) 57-65.

Bielecki, S., Kaıpó chrześcijanina w ujęciu listów św. Pawła (Lublin: RW KUL 1996).

Calduch-Benages, N., En el crisol de la prueba. Estudio exegético de Sir 2,1-18 (Asocianión Biblica Española 32; Estella: Verbo Divino 1997).

Calduch-Benages, N., Un gioiello di sapienza. Leggendo Siracide 2 (Cammini dello Spirito Biblica 45, Milano: Paoline 2001).

Calduch-Benages, N. - Ferrer, J. - Liesen, J. (red.), La Sabiduría del Escriba. Wisdom of the Scribe (Biblioteca Midrásica 26; Estella: Verbo Divino 2003).

Calduch-Benages, N., „ «Prepara il tuo animo alla prova». La prova nel libro di Ben Sira”, Parola Spirito e Vita 55 (2007) 53-68.

Clements, R. E., „ריר:", Theologisches Wörterbuch zum Alten Testament (red. G. J. Botterweck H. Ringgren) (Stuttgart: Kohlhammer 1982) III, 939-947. 


\section{UŻYCIE SŁOWA „CZAS” W KSIĘDZE SYRACYDESA}

Delling, G., „кaıрóৎ”, Theological Dictionary of the New Testament (red. G. Kittel - G. Friedrich) (Grand Rapids, MI: Eerdmans 1995) III, 455-462.

Delling, G., „Хpóvoc”, Theological Dictionary of the New Testament (red. G. Kittel - G. Friedrich) (Grand Rapids, MI: Eerdmans 1995) IX, 581-593.

Demitrów, A., Quattro oranti nell'elogio dei padri (Sir 44-49). Studio dei testi e delle tradizioni (Opolska Biblioteka Teologiczna 124; Opole: Redakcja Wydawnictw Wydziału Teologicznego Uniwersytetu Opolskiego 2011)

Gilbert, M., „Il concetto di tempo (עֵ) in Qohelet e Ben Sira”, Il libro di Qohelet. Tradizione, redazione, teologia (red. G. Bellia - A. Passaro) (Cinisello Balsamo: San Paolo 2001) 69-89.

Gilbert, M., „Laction de grâce de Ben Sira (Si 51,1-12)”, Ce Dieu qui vient. Mélanges B. Renaud (red. R. Kuntzmann) (Lectio Divina 159; Paris: Cerf 1995) 231-242.

Gilbert, M., „ «N’empêche pas la musique!»(Si 32,1-6)”, Toute la sagesse du monde. Hommage à Maurice Gilbert (red. F. Mies) (Le livre et le rouleau 7; Namur-Bruxelles: Lessius 1999) 699-706.

Gilbert, M., Les cinq livres des Sages. Proverbes - Job - Qohélet - Ben Sira - Sagesse (Lire la Bible 129; Paris:Cerf 2003).

Fox, M.V., A Time to Tear Down and A Time to Build Up. A Rereading of Ecclesiastes (Grand Rapids, MI: Eerdmans 1999) 194-206.

Hildesheim, R., Bis daß ein Prophet aufstand wie Feuer. Untersuchungen zum Prophetenverständnis des Ben Sira in Sir 48,1-49,16 (Trierer Theologische Studien 58; Trier: Paulinus 1996).

Join-Lambert, M. - Grelot, P., „Czas”, Słownik teologii biblijnej (red. X. Léon-Dufour) (Poznań: Pallottinum 1990) 175.

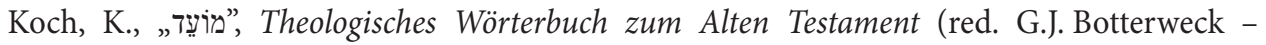
H. Ringgren) (Stuttgart: Kohlhammer 1982) IV, 744-750.

Koehler, L. - Baumgartner, W. - Stamm, J.J. - Dec, P. (red.), Wielki słownik hebrajsko-polski i aramejsko-polski Starego Testamentu (Prymasowska Seria Biblijna 30; Warszawa: Vocatio 2008) I-II (= HALAT).

Jankowski, A., Biblijna teologia czasu, wyd. 2 (Kraków: Tyniec Wydawnictwo Benedyktynów 2018).

Jenni, E., „עת", Theologisches Handwörterbuch zum Alten Testament, wyd. 5 (red. E. Jenni C. Westermann) (Gütersloh: Kaiser - Gütersloher 1994) II, 370-385.

Kronholm, T., „עצ", Theologisches Wörterbuch zum Alten Testament (red. G.J. Botterweck H. Ringgren) (Stuttgart: Kohlhammer 1982) VI, 464-483.

Kuśmirek, A. (red.), Prorocy. Hebrajsko-polski Stary Testament. Przekład interlinearny z kodami gramatycznymi, transliteracja i indeksem słów hebrajskich (Prymasowska Seria Biblijna 27; Warszawa: Vocatio 2008).

Maertens, T., Léloge des Pères (Ecclésiastique 44-50) (Collection Lumière et Vie 5; Bruges: Abbaye de Sant'André 1956).

Massouh, S.B. - Verhoef, P.A., „yerah", New International Dictionary of Old Testament Theology and Exegesis (red. W.A. VanGemeren) (Carlisle: Paternoster 1996) II, 540.

Montanari, F., Vocabolario della lingua greca, wyd. 2 (Torino: Loercher 2004).

Muilenburg, J., „The biblical View of Time”, Harvard Theological Review 54/4 (1961) 225-252.

Muraoka, T., A Greek-English Lexicon of the Septuagint (Louvain - Paris - Walpole, MA: Peeters 2009). 


\section{ANDRZEJ DEMITRÓW}

Langkammer, H., Księga Syracha. Wstęp - przekład z oryginału - komentarz - ekskursy (Pismo Święte Starego Testamentu 7/5; Poznań: Pallotttinum 2020).

Le Maistre de Sacy, L'Ecclésiastique traduit en français avec une expication tirée des Saints Pères et des Auteurs Ecclésiastiques (Paris 1684).

Liddell, H.G. - Scott, R., A Greek-English Lexicon, wyd. 10 (Oxford: Clarendon 1996).

Liesen, J., Full of Praise. An Exegetical Study of Sir 39,12-35 (Journal for the Study of Judaism. Supplements 64; Leiden - Boston, MA - Köln: Brill 2000).

Lipiński, E., „נקם", Theologisches Wörterbuch zum Alten Testament (red. G.J. Botterweck H. Ringgren) (Stuttgart: Kohlhammer 1982) V, 602-612.

Lohfink, N., „Le temps dans le livre de Qohélet”, Christus 32 (1985) 69-80.

Lust, J. - Eynikel, E. - Hauspie, K., A Greek-English Lexicon of the Septuagint (Stuttgart: Deutsche Bibelgesellschaft 1996) I-II.

Lys, D., L'Ecclésiaste ou que vaut la vie? (Paris: Letouzay \& Ané 1977) 302-345.

Obruśnik, M., „Księga Syracydesa w świetle niektórych zagadnień historyczno-krytycznych”, „Sanctificetur Nomen Tuum” (Mt 6,9). Ksiega Pamiątkowa dedykowana ks. Prof. J. Czerskiemu z okazji 65. rocznicy urodzin i 38. lat pracy naukowo-dydaktycznej (red. B. Polok K. Ziaja) (Opolska Biblioteka Teologiczna 40; Opole: Wydział Teologiczny Uniwersytetu Opolskiego 2000) 59-69.

Palmisano, M.C., "Salvaci, Dio dell'universo". Studio delleucologia di Sir 36H,1-17 (Analecta Biblica 163; Roma: Pontificio Istituto Biblico 2006).

Palmisano, M.C. (red.), Siracide. Introduzione, traduzione e commento (Nuova versione della Bibbia dai Testi Antichi 34; Cinisello Balsamo: San Paolo 2016).

Peels, H.G.L., The Vengeance of God. The Meaning of the Root NQM and Function of the NQMTexts in the Context of Divine Revelation in the Old Testament (Oudtestamentische Studiën 31; Leiden - New York - Köln 1995).

Petraglio, R., Il libro che contamina le mani. Ben Sirac rilegge il libro e la storia d'Israele (Teologia 4; Palermo: Augustinus 1993).

Piwowar, A., „Wierność w czasie próby (Syr 2,1-6)”, Verbum Vitae 11 (2007) 99-126.

Piwowar, A. „La storia testuale del Libro del Siracide”, Roczniki Teologiczne 55/1 (2008) 31-53.

Piwowar, A., „Firmament i ciała niebieskie świadkami Boga (Syr 43,1-12)”, Biblical Annals 7/1 (2017) 5-48.

Popielewski, W., „Między kruchością a wielkością człowieka. Refleksja Syracha nad tajemnicą ludzkiego istnienia", Verbum Vitae 15 (2009) 61-84.

Prato, G.L., Il problema della teodicea in Ben Sira (Analecta Biblica 65; Rome: Biblical Institute Press 1975).

Pudełko, J.J., „Periodyzacja dziejów Izraela w Pochwale Ojców Księgi Syracha (Syr 44-49)”, Verbum Vitae 35 (2019) 39-76.

von Rad, G., La sapienza in Israele (Collana biblica; Torino: Marietti 1975).

Rahlfs, A. - Hanhart, R. (red.), Septuaginta. Id est Vetus Testamentum graece iuxta LXX interpretes, wyd. 2 (Stuttgart: Deutsche Bibelgesellschaft 2006) I-II.

Romizi, R., Greco antico. Vocabolario greco italiano etimologico e raggionato, wyd. 3 (Bologna: Zanichelli 2007).

Sacchi, P., „Il problema del tempo in Qohelet”, Parole Spirito e Vita 36 (1997) 73-83. 


\section{UŻYCIE SŁOWA „CZAS” W KSIĘDZE SYRACYDESA}

Sasse, H., „aíwv, aíwvıৎ”, Theological Dictionary of the New Testament (red. G. Kittel - G. Friedrich) (Grand Rapids, MI: Eerdmans 1995) I, 198-202.

Sauer, G., Jesus Sirach / Ben Sira (Das Alte Testament Deutsch. Apokryphen 1; Göttingen: Vandenhoeck \& Ruprecht 2000).

Sauer, G., „נקם", Theologisches Handwörterbuch zum Alten Testament, wyd. 5 (red. E. Jenni C. Westermann) (Gütersloh: Kaiser - Gütersloher 1994) II, 106-109.

Schreiner, J., Jesus Sirach 1-24. Kommentar zum AT mit der Einheitsübersetzung (Die Neue Echter Bibel 38; Würzburg: Echter 2002).

Skehan, P.W. - Di Lella, A.A., Wisdom of Ben Sira. A New Translation with Notes by Patrick W. Skehan. Introduction and Commentary by Alexander A. Di Lella (Anchor Bible 39; New York: Doubleday 1987).

Stachowiak, L., „Teologiczno-biblijna problematyka czasu”, Ruch Biblijny i Liturgiczny 17/4 (1964) 291-303.

de Vaux, R., Instytucje Starego Testamentu (Poznań: Pallottinum 2004).

Wagner, M., „קץ", Theologisches Handwörterbuch zum Alten Testament, wyd. 5 (red. E. Jenni C. Westermann) (Gütersloh: Kaiser - Gütersloher 1994) II, 659-663.

Wilch, J.R., Time and Event. An Exegetical Study of the Use of 'eth in the Old Testament in Comparison to Other Temporal Expressions in Clarification of the Concept of Time (Leiden: Brill 1969).

Wojciechowski, M. (red.), Księgi greckie. Grecko-polski Stary Testament. Przekład interlinearny $z$ kodami gramatycznymi i indeksem form podstawowych (Prymasowska Seria Biblijna 31; Warszawa: Vocatio 2008).

Zapff, B.M., Jesus Sirach 25-51. Kommentar zum AT mit der Einheitsübersetzung (Die Neue Echter Bibel 39; Würzburg: Echter 2010).

Ziegler, J. (red.), Sapientia Jesu Filii Sirach, wyd. 2 (Septuaginta 12/2; Göttingen: Vandenhoeck \& Ruprecht 1980). 
